doi: $10.1017 /$ jpa.2021.37

\title{
Systematics of the Early Ordovician (late Tremadocian; Stairsian) trilobite Gonioteloides Kobayashi, with species from the Great Basin, western USA
}

\author{
Jonathan M. Adrain ${ }^{1} \oplus$ and Talia S. Karim² \\ ${ }^{1}$ Department of Earth and Environmental Sciences, 115 Trowbridge Hall, University of Iowa, Iowa City, Iowa 52242, USA \\ $<$ jonathan-adrain@uiowa.edu> \\ ${ }^{2}$ University of Colorado Museum of Natural History, 265 UCB, University of Colorado, Boulder, CO 80309, USA <talia.karim@ colorado.edu>
}

\begin{abstract}
The Early Ordovician (late Tremadocian; Stairsian) trilobite Gonioteloides Kobayashi has long been known from a small number of pygidia assigned to a single formally named species, and its affinities have not been assessed. Silicified material from western Utah and southeastern Idaho includes six distinct species assigned to the genus, one of which is the type species. Two others (G. moffitti and G. pankowskii) are new and formally named. An additional three species that are clearly new but known from sparse material are described in open nomenclature. Gonioteloides has a stratigraphic distribution through five consecutive trilobite zones in the mid-Stairsian Stage (upper Tremadocian). Although exoskeletal morphology of three species is almost completely known, the phylogenetic affinity of the taxon remains difficult to determine. It is tentatively assigned to Dimeropygidae Hupé.
\end{abstract}

UUID: http://zoobank.org/23257d6c-262b-4ef5-ae4e-cc431777e67e

\section{Introduction}

Gonioteloides Kobayashi, 1955, is one of several trilobite genera from the Lower Ordovician of the northern paleo-margin of Laurentia that have been very poorly known and whose affinities have been obscure. Kobayashi based the genus on two species (regarded herein as subjective synonyms) and a total of four specimens, all pygidia and all from the McKay Group of southeastern British Columbia, Canada. Dean (1989) referred a fragmentary pygidium from the middle member of the Survey Peak Formation, Jasper National Park, Alberta to the genus. The only other specimen directly assigned to the genus prior to the work of Adrain et al. (2014a) was a pygidium from the Manitou Formation of Colorado described by Berg and Ross (1959) as Gonioteloides sp. cf. G. monoceros Kobayashi. Hence, the genus has historically been known only from six directly assigned specimens, all pygidia.

In the course of an extended field-based revision of the primarily silicified Lower and Middle Ordovician faunas of the Great Basin (Adrain et al., 2009, 2014a), material assignable to species of Gonioteloides proved to be quite common at some Stairsian horizons (some cranidia and pygidia were illustrated in the biostratigraphic work of Adrain et al., 2014a). Six distinct species have been recovered from localities in western Utah and southeastern Idaho, including the type species, and we now have knowledge of most exoskeletal parts. The goals of this work are to: (1) describe the morphology of members of the genus, including for the first time sclerites other than pygidia; (2) describe three formally named species (the type and two new) and three others reported in open nomenclature; (3) document the stratigraphic occurrence of the species; and (4) assess the affinities of the genus based on the new information.

\section{Localities and stratigraphy}

Details of the history of study, sections, and stratigraphy for localities referenced herein were given by Adrain et al. (2014a), including maps for all lines of sections and stratigraphic logs for the lower Fillmore Formation at Section MME (Middle Mountain), Section AAA (northern House Range), and the basal part of Section C (southern House Range) in the Ibex area, western Utah, and for the Stairsian strata of the Garden City Formation at Section HC5 and Section HC6 (both Hillyard Canyon) in the Bear River Range, southeastern Idaho. A stratigraphic log for the Fillmore Formation at Section G (southern Confusion Range) in the Ibex area was given by Adrain et al. (2009). A log for the Garden City Formation at Section FB7 (Franklin Basin) in the Bear River Range has not been published in detail, but a reduced $\log$ including the Stairsian interval was given by Adrain et al. (2014a, fig. 4). Material from only a single horizon at FB7, $102.1 \mathrm{~m}$, is described herein. This horizon is assigned to the Bearriverops loganensis Zone of Adrain et al. (2014a) and its fauna is identical to that of Section HC5 $106.7 \mathrm{~m}$. The trilobite zonation of Adrain et al. (2014a) is followed herein. Adrain et al. (2014a, fig. 4) depicted the zonation and correlation of all of the sections and horizons from which material is described. The geographic and zonal distribution of species treated are given in Figure 1. 


\begin{tabular}{|c|c|c|c|c|c|c|}
\hline \multirow{2}{*}{$\begin{array}{c}\text { Zones } \\
\text { (Adrain et al., 2014a) }\end{array}$} & \multicolumn{3}{|c|}{ Western Utah } & \multicolumn{3}{|c|}{ Southeastern Idaho } \\
\hline & $\begin{array}{l}\text { Section C } \\
\text { Southern House } \\
\text { Range }\end{array}$ & $\begin{array}{c}\text { Section G } \\
\text { Southern Confusion } \\
\text { Range }\end{array}$ & $\begin{array}{c}\text { Section MME } \\
\text { Middle } \\
\text { Mountain }\end{array}$ & $\begin{array}{c}\text { Section FB7 } \\
\text { Franklin } \\
\text { Basin }\end{array}$ & $\begin{array}{l}\text { Section HC5 } \\
\text { Hillyard Canyon } \\
\text { East Side }\end{array}$ & $\begin{array}{c}\text { Section HC6 } \\
\text { Hillyard Canyon } \\
\text { West Crest }\end{array}$ \\
\hline \multicolumn{7}{|l|}{$\begin{array}{l}\uparrow \text { Stairsian } \\
\text { Continues }\end{array}$} \\
\hline $\begin{array}{c}\text { Bearriverops } \\
\text { alsacharovi }\end{array}$ & $\begin{array}{c}\text { G. monoceros } \\
\text { Kobayashi, } 1955\end{array}$ & $\begin{array}{c}\text { G. monoceros } \\
\text { Kobayashi, } 1955 \\
\text { G. n. sp. C }\end{array}$ & & & & $\begin{array}{c}\text { G. monoceros } \\
\text { Kobayashi, } 1955\end{array}$ \\
\hline $\begin{array}{c}\text { Bearriverops } \\
\text { deltaensis }\end{array}$ & & & $\begin{array}{c}\text { G. n. sp. B } \\
\text { G. pankowskii n. sp. }\end{array}$ & & & \\
\hline $\begin{array}{c}\text { Bearriverops } \\
\text { loganensis }\end{array}$ & & & $\begin{array}{c}\text { Gonioteloides } \\
\text { pankowskii n. sp. }\end{array}$ & $\begin{array}{c}\text { Gonioteloides } \\
\text { pankowskii n. sp. }\end{array}$ & $\begin{array}{c}\text { Gonioteloides } \\
\text { pankowskii n. sp. }\end{array}$ & $\begin{array}{c}\text { Gonioteloides } \\
\text { pankowskii n. sp. }\end{array}$ \\
\hline $\begin{array}{l}\text { Unnamed } \\
\text { Zone } 1\end{array}$ & & & G. n. sp. A & & & \\
\hline $\begin{array}{l}\text { Rossaspis } \\
\text { leboni }\end{array}$ & & $\begin{array}{l}\text { Gonioteloides } \\
\text { moffitti in. sp. }\end{array}$ & & & & \\
\hline $\begin{array}{c}\text { Stairsian } \\
\text { Continues } \downarrow\end{array}$ & & & & & & \\
\hline
\end{tabular}

Figure 1. Occurrence chart for species of Gonioteloides treated herein. Full details of localities, stratigraphy, and zonation are given by Adrain et al. (2014a).

\section{History of study}

Gonioteloides is rarely referred to in the trilobite literature because little has previously been known about it. Kobayashi (1955) proposed two species from the Lower Ordovician McKay Group of British Columbia, Canada: G. monoceros (the type) and G. punctatus (considered a synonym of G. monoceros herein). The former was based only on three illustrated pygidia (Kobayashi, 1955, pl. 6, figs. 17, 18, pl. 8, fig. 10) and the latter on a single pygidium (Kobayashi, 1955, pl. 6, fig. 19). Subsequently, Berg and Ross (1959, p. 117, pl. 21, figs. 8, 9) assigned a single pygidium from the Manitou Formation, Colorado, to Gonioteloides sp. cf. G. monoceros. Terrell (1973, pl. 5, fig. 15), in a paper on Stairisan faunas of the Ibex area in western Utah, illustrated a left librigena as "unassigned." With the material described herein, it is clear that this specimen belongs to a species of Gonioteloides. However, the ventrolateral orientation of Terrell's photograph precludes confident assignment at the species level. Dean (1989, p. 26, pl. 27, figs. $4,5)$ reillustrated the holotype of $G$. monoceros and assigned a fragmentary pygidium (Dean, 1989, pl. 27, fig. 6) from the Survey Peak Formation in Alberta to the species. Prior to the present work, this is the sum total of material known for the genus, apart from specimens of some of the species treated herein, which were illustrated in a biostratigraphic zonation work by Adrain et al. (2014a). It is notable that not a single sclerite of any species of Gonioteloides was illustrated in either Ross's (1951) monograph of the faunas of the Garden City Formation in southeastern Idaho or Hintze's (1953) publication on the Pogonip Group in western Utah. It is not clear why this is so because some of the species are quite common at certain horizons and many of the taxa that occur with them were illustrated and even formally named in these classic works.
Berg and Ross (1959, p. 118), Norford (1969, p. 4), and Dean (1978, p. 7; 1989, p. 26) have commented on Kobayashi's claim that the genus occurs in strata of both his "Kainella-Evansaspis fauna" (Kobayashi, 1955, table 4), which would be broadly equivalent to Ross's $(1949,1951)$ zones E and F (now Stairsian) and to his "Symphysurina Fauna" (Kobayashi, 1955, table 3), which is equivalent to Ross's Zone B (Skullrockian). As Norford (1969, p. 4) pointed out, the supposed Skullrockian occurrence of G. monoceros must either have been due to Kobayashi's (1955) locality 19 spanning several zones or else it was simply a mistake. No other Stairsian species are listed in Kobayashi's (1955) table 3, and the specimen in question (Kobayashi, 1955, pl. 8, fig. 9) seems certain to be conspecific with the others he illustrated and with the silicified material assigned herein. Hence, the Skullrockian age was almost certainly an error, as Dean (1989, p. 12) also concluded. In our extensive field sampling, we have found species of the genus only in mid-Stairsian strata.

\section{Materials}

Repositories and institutional abbreviations.-The type specimens of the type species are housed in the collections of the Geological Survey of Canada, with specimen number prefix GSC. New type and figured material is housed in the Paleontology Repository, Department of Earth and Environmental Sciences, University of Iowa, Iowa City, with specimen number prefix SUI.

\section{Systematic paleontology}

Order of description.-The type species is revised first, then species are described in ascending stratigraphic order by morphological group. 
Family ?Dimeropygidae Hupé, 1953

Genus Gonioteloides Kobayashi, 1955

Type species.-Gonioteloides monoceros Kobayashi, 1955, from the McKay Group (upper Tremadocian; Stairsian) of British Columbia, Canada.

Other species.-Gonioteloides moffitti n. sp., Fillmore Formation (upper Tremadocian; Stairsian; Rossaspis leboni Zone), western Utah; G. pankowskii n. sp., Fillmore Formation, western Utah, and Garden City Formation, southeastern Idaho, USA (both upper Tremadocian; Stairsian; Bearriverops loganensis Zone); Gonioteloides n. sp. A, Fillmore Formation, western Utah (upper Tremadocian; Stairsian; Unnamed Zone 1 of Adrain et al., 2014a); Gonioteloides n. sp. B, Fillmore Formation, western Utah (upper Tremadocian; Stairsian; Bearriverops deltaensis Zone); Gonioteloides n. sp. C, Fillmore Formation, western Utah (upper Tremadocian; Stairsian; Bearriverops alsacharovi Zone); "Gonioteloides sp. cf. G. monoceros Kobayashi” of Berg and Ross (1959, p. 117, pl. 21, figs. 8, 9), Manitou Formation (upper Tremadocian; Stairsian), Williams Canyon, Manitou Springs, El Paso County, Colorado, USA.

Diagnosis.-Dorsal surfaces mostly smooth, almost entirely lacking tuberculate sculpture; preglabellar field medially very short to absent; glabella long and broad, with slight lateral constriction just posterior to or aligned with front edge of palpebral lobe to give subtle "fiddle" shape; glabellar furrows completely effaced, even ventrally; eyes large (about half length of glabella) to very large (more than four-fifths length of glabella); interocular fixigena broad; palpebral lobe well defined by deep palpebral furrow; fixigenal posterior projections narrow (tr.) and short (exsag.); eye with narrow, but well-defined socle; librigenal field broad and featureless; anterior and lateral borders with sculpture of fine raised lines; genal spine in large specimens short and slender; thorax with axial and pleural lobes about the same width; thoracic posterior pleural bands slightly longer than anterior pleural bands, pleural furrow deep; thoracic pleural tips blunt and subquadrate, with short but prominent pleural spine; pygidium with three obvious axial rings, weakly differentiated fourth present in some specimens of some species; three pygidial pleural furrows expressed, weakly expressed fourth in some specimens of some species; pygidium with vertical "wall" beneath pleural tips, connecting to strongly inflated, rim-like border; pygidial pleural tips form linear ridge atop "wall;" rear of axis and, in some species, apparently rear parts of pleurae extended posteriorly into posterior projection or spine with widely varying morphology.

Remarks.-When he named Gonioteloides, Kobayashi (1955, p. 446) assigned the genus to Bathyuridae Walcott, 1886, although he acknowledged that its "family reference cannot be warranted until its cephalon will be found." Whittington in Moore (1959, p. O380) listed Gonioteloides with Bathyuridae, but without either a diagnosis or an illustration. The genus was discussed by Fortey (1979, p. 74) as Bathyuridae (with reservation owing to absence of knowledge of the cephalon) and it was assigned to the family by Ross $(1975$, p. 315 , table 1$)$ and
Dean (1989). Finally, Fortey and Bruton (2013, p. 21) included Gonioteloides in a list of problematic bathyurid genera. Hence, most workers have treated the genus, with considerable reservation given all that was known, as probable Bathyuridae.

Berg and Ross (1959, p. 117) are an exception, having made no family assignment when they described in open nomenclature what has, until now, been the only other species known (although Dean, 1989, p. 26 listed their specimen as belonging to $G$. monoceros). However, they made comparisons with the species Psalikilus spinosum Hintze, 1953, and Psalikilopsis cuspidicauda Ross, 1953. In fact, both of these comparisons are to Psalikilopsis because the pygidium illustrated by Hintze (1953, pl. 9, figs. 7-9) as Psalikilus spinosum was misassigned and belongs to what is now Psalikilopsis redfordi Adrain et al., 2011. Psalikilopsis is an unambiguous bathyurid, but apart from having a posterior spine or extension behind the pygidial axis, no other aspects of its morphology resemble what is now known of Gonioteloides.

Adrain et al. (2003, p. 560), citing unpublished data (the specimens described herein that had been discovered to that point), considered the affinities of Gonioteloides to be uncertain. Adrain (in Jell and Adrain, 2003, p. 380) also listed it as such.

Before discussing its morphology, it is worth reviewing how stratigraphically anomalous a bathyurid affinity for Gonioteloides would be. Bathyurids are among the most common trilobites of the Laurentian Tulean and Blackhillsian stages. However only a single Laurentian Stairsian genus, Randaynia Boyce, 1989, has been assigned to the family. The affinities of this taxon are a matter of debate. Boyce $(1989$, p. 62) proposed it as "Family Incertae Sedis," yet held that it compared closely with the Skullrockian asaphids Bellefontia Ulrich in Walcott, 1924, and Parabellefontia Hintze, 1953. In contrast, Westrop et al. (1993, p. 1629-1631) considered Randaynia a bathyurelline bathyurid related to taxa such as Uromystrum Whittington, 1953. Adrain in Jell and Adrain (2003, p. 438), Loch (2007, p. 70), and Adrain and Westrop in Landing et al. (2012, p. 113) all assigned the genus to Bathyuridae. Fortey and Bruton (2013, p. 107), on the other hand, made the strikingly novel assertion that Randaynia is closely related to the latest Cambrian to earliest Stairsian genus Symphysurina Ulrich in Walcott, 1924. Together with a new genus, Eurysymphysurina, they assigned the genera to the family Symphysurinidae Kobayashi, 1955, and the asaphide superfamily Cyclopygoidea Raymond, 1925. We will defer assessment of Symphysurinidae until a forthcoming work on Symphysurina. Of importance here is that, if Fortey and Bruton (2013) are correct, then there are no known bathyurids in the Laurentian Stairsian. Even if they are not correct about an asaphide affinity for Randaynia, it is certainly true that some aspects of its morphology, particularly the number of pygidial axial segments, are difficult to reconcile with bathyurids, and its classification will likely not be resolved until better material, particularly knowledge of ventral cephalic morphology and the hypostome, of an assigned species is discovered.

Hence, if Gonioteloides is a bathyurid, it would be the only definitely assigned Laurentian Stairsian example. However, discovery of abundant cephalic material of the type species, and of five additional new species, does not support a bathyurid affinity.

Despite only six distinct species now having been found, there is a striking amount of morphological disparity in the 
group. The species are united in having cephala lacking dorsal sculpture apart from fine raised lines on the border, large glabellae that contact or nearly contact the anterior border furrow, inflated anterior and lateral borders, and, in particular, very large eyes with concomitantly long palpebral lobes. The pygidium is known for five of the species, and in all cases it has a very broad axis and some form of posterior extension of the rear of the axis, past the underlying posterior margin of the border. There are two main morphological groups, and they are different enough that they could potentially be classified as distinct genera, although this should be evaluated when more knowledge of the group's diversity is discovered. The first group, including $G$. monoceros, G. moffitti n. sp., G. n. sp. A, and G. n. sp. B, features species with highly vaulted cephala and pygidia with a distinct spine for the posterior pygidial extension. The spine ranges from relatively short and blunt (G. n. sp. B) to longer and blunt (G. monoceros) to elongate, narrow, and cylindrical (G. moffitti n. sp.) to elongate and very robust, with an elaborate dorsal keel (G. n. sp. A). A second group, including G. pankowskii n. sp. and $G$. n. sp. C, features much less vaulted cephala and pygidia (known only for G. pankowskii n. sp.) with a posterior projection that is not spine-like, but rather a short, lobate extension of the lateral ridges against which the pleural furrows terminate. The first group includes the oldest known species, G. moffitti n. sp., but all of the species occur in a relatively narrow stratigraphic interval (at Section MME, including the correlative position of horizons from other sections, the genus ranges through $\sim 66 \mathrm{~m}$ of section). The morphology of individual species is disparate, and no obvious morphological trends are correlated with stratigraphy.

Generally effaced trilobites often present taxonomic difficulties. As noted previously, the pygidial posterior projections have drawn comparison to those of species of the bathyurid $P s a$ likilopsis, which is known exclusively from the overlying Tulean Stage. Psalikilopsis was assessed on the basis of revised and new species by Adrain et al. (2011). It is true that pygidia of the two taxa are very similar in many ways. They both feature a more or less vertical "wall" developed above the pygidial border. In both cases, this wall is topped by lateral ridges against which the pleural and interpleural furrows terminate. They both have four axial rings. The lateral ridges unite posteriorly to form a projection. However, all other aspects of the morphology of species of Psalikilopsis indicate that it is a bathyurid. The oldest known species assigned, P. newmani Adrain et al., 2011, has a standard bathyurid pygidium lacking the "wall" and posterior projection, even while most of its cranidial and thoracic segment morphology is nearly identical with that of derived younger species. There seems little doubt that the pygidial features of derived species of the younger taxon are convergent on those of Gonioteloides, and not indicative of relationship. Bathyurids in general fall into two broad morphological groups. One features species that are moderately vaulted, highly tuberculate, and often with a posteromedian pygidial spine, which is almost never associated with a vertical "walled" border (e.g., species of Acidiphorus Raymond, 1925). A second features species with lower dorsal vaulting, common effacement, and flattened, fan-shaped pygidia. Theses have been formalized as Bathyurinae Walcott, 1886, and Bathyurellinae Hupé, 1953, respectively, by Fortey (1979). Neither is morphologically similar to Gonioteloides.
The only contemporaneous group that Gonioteloides resembles is Dimeropygidae, although there is not enough information to establish a clear affinity. Dimeropygids are generally strongly dorsally vaulted and highly tuberculate, although some effaced taxa are assigned. The highly vaulted cephalic morphology of the oldest species, G. moffitti n. sp., with the glabella abutting the anterior border, and the general morphology of the librigenae, with a tendency toward loss of the genal spine in larger individuals of some species, are consistent with dimeropygids. "Walled" pygidia are also developed in some dimeropygid genera, including Dimeropyge Öpik, 1937, itself, Heckethornia McAdams and Adrain, 2009, and Pseudohystricurus Ross, 1951 (see Adrain et al., 2014b). Most dimeropygids, however, are highly tuberculate or spiny. Among contemporaneous taxa, some species of Bearriverops Adrain and Westrop, 2007, are relatively effaced, but most have dense, if somewhat subdued, tuberculate sculpture over all dorsal surfaces and the effaced species are derived within the clade, according to cladistic analysis (Adrain and Westrop, 2007, fig. 5.1). In Gonioteloides, even the smallest known cranidia (e.g., Fig. 10.21) show no sign of any sculpture.

It must be mentioned that Adrain et al. (2014b, p. 216) made reference to "a species assigned by us in a forthcoming work to a new genus closely related to Gonioteloides..." This species was illustrated by Adrain et al. (2014a, p. 179, fig. $12 \mathrm{D}, \mathrm{H})$ as "Dimeropygidae gen. nov. $1 \mathrm{sp}$. nov. 1." It is a highly tuberculate and vaulted species that by every indication is a typical dimeropygid. Its cranidial dimensions are a fairly close match for those of G. moffitti n. sp. It has a "walled" pygidium and it has lateral pygidial ridges against which the pleural and interpleural furrows terminate. These ridges unite posteriorly to form a small, pointed, posterior projection. It remains at least conceivable that this as yet unpublished new genus is the more conventional dimeropygid sister taxon to the effaced Gonioteloides (it occurs with the stratigraphic range of the latter-found with G. pankowskii n. sp. in the Bearriverops alsacharovi Zone). In light of the broader knowledge of species of Gonioteloides documented herein, and the complete lack of any tuberculate sculpture in any species at any ontogenetic stage, we are now more equivocal about the possibility of close relationship, though it should not be excluded as a possibility.

Lee and Chatterton (1997) illustrated a set of protaspid larvae from the Garden City Formation in southeastern Idaho as what they termed "Proetide A." The protaspids feature no paired glabellar or fixigenal spines, are strongly micropygous, and have glabellar segments transected medially so that they are divided into a pair of lateral swellings. They do not resemble those of any known members of the Order Aulacopleurida (see Adrain, 2011, 2013), including the dimeropygids (e.g., Chatterton, 1994). Lee and Chatterton (1997) associated two small cranidia with these protaspids that clearly represent a species of Gonioteloides, likely G. pankowskii n. sp. (cf., Lee and Chatterton, 1997, fig. 2.12; Fig. 10.21). If this association is correct, then the affinities of Gonioteloides are obscure because the protaspids are morphologically unique among known Early Ordovician trilobites. However, it is not clear that the association is correct. The smallest of the cranidia (Lee and Chatterton, 1997, fig. 2.13) is essentially the same size as the 
protocranidium of the largest assigned protaspis (Lee and Chatterton, 1997, fig. 2.11), but the protocranidium of the protaspid has obviously different morphology than the cranidium, including a glabella with subparallel sides (versus narrowing strongly anteriorly), prominent transverse furrows (versus weak furrows that are not obviously transverse), a long anterior border with a transversely straight margin (versus short and anteriorly bowed), and much smaller palpebral lobes. Based on their nearly identical size, the tiny cranidium would presumably represent a degree zero meraspid. For it to belong with the protaspids, there would have to have been no size increase in the molt between the last protaspid instar and the first meraspid instar, while the cranidium nevertheless underwent radical morphological change. Hence it seems implausible that the Gonioteloides cranidia are properly associated. The cooccurring trilobite fauna is very diverse and still largely undescribed or unrevised, and what the protaspids actually represent is still unknown.

For the present, we assign Gonioteloides with significant question to Dimeropygidae, based on the broad cephalic similarities of the dorsally vaulted $M$. moffitti n. sp. and potential relationship with "Dimeropygidae gen. nov. 1 sp. nov. 1" of Adrain et al. (2014b). Unusually for an Ordovician trilobite with most sclerites reasonably well known, its affinity largely remains an open question. Discovery of more species and of convincingly associated early growth stages are most likely to help inform the problem.

Although the axial pygidial region of most specimens of most species of Gonioteloides appears to indicate three pygidial segments, various lines of evidence suggest that the basic plan for the genus, probably shared by all species, is a four segment pygidium with the posteriormost fourth segment difficult to distinguish from a terminal piece and the base of the posterior lobe or spine. Many species, for example, have a short fourth pleural furrow expressed, flanking the base of the spine. In rare specimens (e.g., Fig. 8.6), a fourth segment appears to be fully expressed, defined posteriorly by a faint fourth ring furrow. In another small specimen with faint axial nodes (Fig. 8.13) the fourth ring is not very obvious, yet there is a faint axial node atop the base of the spine, indicating the segment's presence.

Brett and Westrop (1996, p. 422, fig. 16.9, 16.10) compared a pygidium from the Fort Cassin Formation (Tulean) of New York, which they described as "Acidiphorus? sp. indet." to Gonioteloides. The pygidium, however, is very similar to those of the bathyurid Psalikilopsis cuspidicauda Ross, 1953, and represents an undescribed species of that genus (Adrain et al., 2011, p. 375).

\section{Gonioteloides monoceros Kobayashi, 1955}

Figures 2, 3

1955 Gonioteloides monoceros Kobayashi, p. 447, pl. 6, figs. 17a, b, 18a, b, pl. 8, fig. 10.

1955 Gonioteloides punctatus Kobayashi, p. 448, pl. 6, fig. 19 a, b.

1959 Gonioteloides monoceros; Berg and Ross, p. 117.

1959 Gonioteloides monoceros; Whittington in Moore, p. $\mathrm{O} 380$.

1967 Gonioteloides monoceras [sic]; Norford in Aitken and Norford, p. 181, 194.
1969 Gonioteloides monoceras [sic]; Norford, p. 4.

1978 Gonioteloides monoceros; Dean, p. 7.

1979 Gonioteloides monoceros; Fortey, p. 74.

1982 Gonioteloides monoceros; Dean in Dean and Martin, p. 135.

1989 Gonioteloides monoceros; Dean, p. 26, pl. 27, figs. 4-6.

2003 Gonioteloides monoceros; Jell and Adrain, p. 380.

2013 Gonioteloides monoceros; Fortey and Bruton, p. 21.

2014a Gonioteloides monoceras [sic]; Adrain et al., p. 179, fig. $12 \mathrm{C}, \mathrm{G}$.

Holotype.—Pygidium, GSC 12697 (Dean, 1989, pl. 27, figs. 4, 5), from the McKay Group (upper Tremadocian; Stairsian), GSC locality 7977, British Columbia, Canada.

Diagnosis.-Cephalon vaulted; preglabellar field absent medially, anterior and preglabellar furrows forming " $\mathrm{X}$ " shape in anterior view; glabella broad anteriorly and markedly waisted behind anterior edges of palpebral lobes; eyes large; fixigenal posterior projections very short (exsag.) and narrow; anterior border tall in anterior view and strongly transversely arched; librigenae with part of posterior border expressed and genal spine reduced to small subtriangular nubbin in largest specimens, short and thorn-like in smaller specimens; pygidium vaulted, with only three axial rings defined; third ring furrow posteriorly bowed in dorsal view; first three pleural furrows deep, fourth shallow, narrow, and flanking large posterior spine; posterior spine broad at base, moderately long, and "drooping" ventrally in lateral view; pleural tips and lateral edge of spine with subparallel raised-line sculpture; border more inflated anteriorly, with oblique raised-line sculpture.

Occurrence.-Section C 111.6 m. Section G $26.6 \mathrm{~m}, \mathrm{G} 27.0 \mathrm{~m}$, and G 27.5T m, Fillmore Formation (upper Tremadocian; Stairsian; Bearriverops alsacharovi Zone), southern Confusion Range, Ibex area, Millard County, western Utah.

Description.-Cranidium known from five specimens illustrated in Figure 2, with measurements made on most-complete specimens and distance to mid-line doubled when morphology preserved only on one side. Cranidium with overall strong dorsoventral relief, with sagittal length $86.0 \%$ (83.9-88.0\%) width across $\delta$, sagittal length $143.9 \%$ (125.2$153.3 \%$ ) width across $\gamma$, sagittal length $105.0 \%$ (103.4$108.0 \%)$ width across $\epsilon$; glabella longer than wide, with length (sag.) $116.8 \%$ (106.3-124.9\%) maximum width (tr.), glabella with lateral margins slightly laterally bowed from posterior margin to point opposite mid-point of palpebral lobe, glabella narrows (tr.) from this point forward with more prominent constriction (tr.) present just behind anterior margin of palpebral lobe (see Fig. 2.17), posterior margin nearly transverse, anterior margin gently rounded, dorsal inflation moderate; anteriormost portion of glabella strongly downturned ventrally (e.g., Fig. 2.6); glabella smooth, lateral glabellar furrows not expressed; axial furrows deeply incised; preglabellar furrow incised, narrow; anterior border furrow and preglabellar furrow meet medially, forming an " $\mathrm{X}$ " in anterior view (Fig. 2.9-2.12); anterior border furrow clearly 


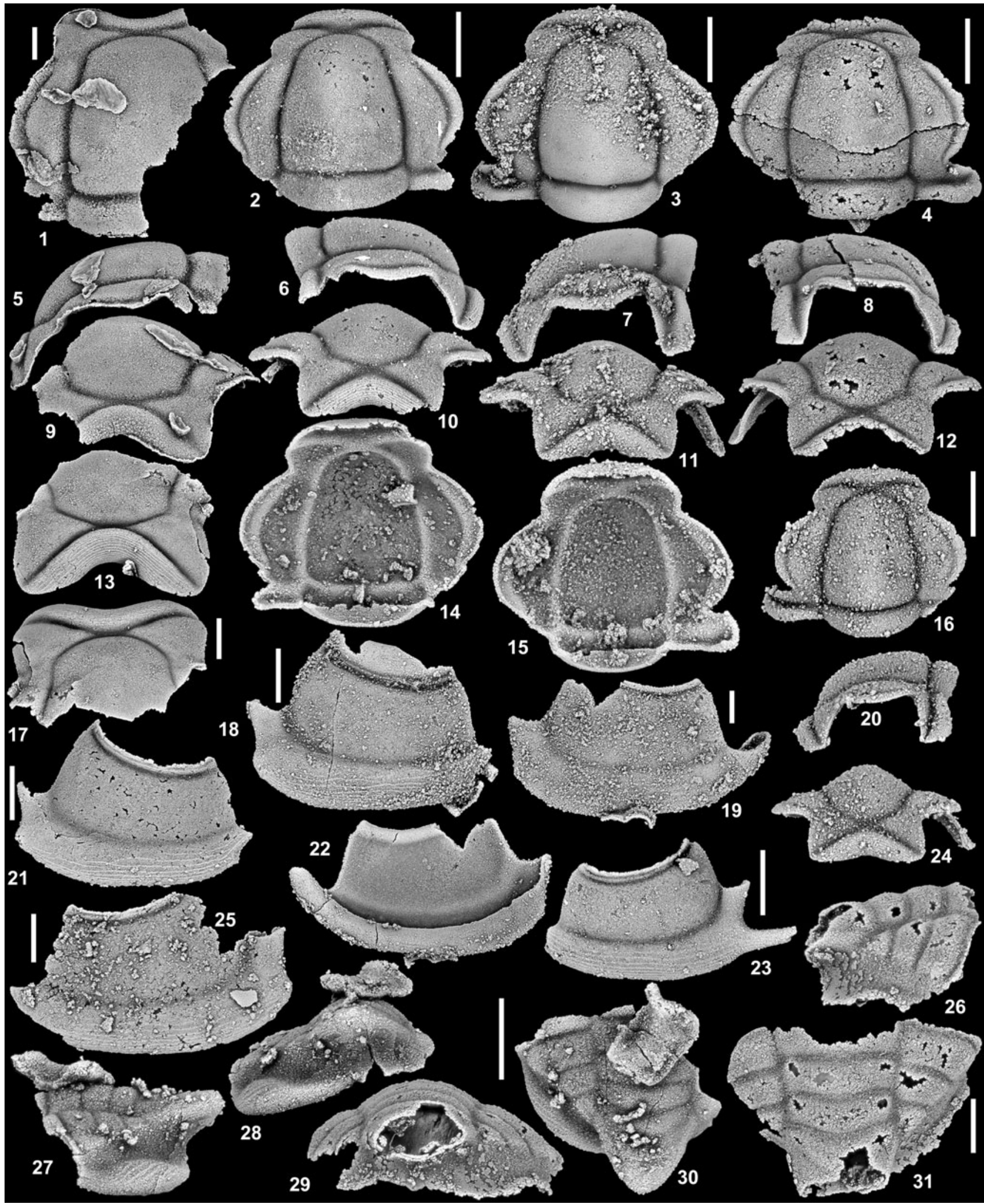

Figure 2. Gonioteloides monoceros Kobayashi, 1955, from Section C 111.6 m, southern House Range, and Section G 26.6 m and 27.0 m, southern Confusion Range, both Fillmore Formation, Ibex area, Millard County, western Utah, USA; and Section HC6 122.5 m, Garden City Formation, west side of Hillyard Canyon, Bear River Range, Franklin County, southeastern Idaho, USA (all upper Tremadocian; Stairsian; Bearriverops alsacharovi Zone). (1, 5, 9) Cranidium, SUI 146990, dorsal, left lateral, and anterior views (HC6 122.5 m); (2, 6, 10, 14) cranidium, SUI 134155, dorsal, right lateral, anterior, and ventral views $(\mathrm{G} 26.6 \mathrm{~m}) ;(\mathbf{3 , 7}, \mathbf{1 1}, \mathbf{1 5}) \mathrm{cranidium}$, SUI 146991, dorsal, left lateral, anterior, and ventral views (G 26.6 m); (4, 8, 12) cranidium, SUI 146992, dorsal, right lateral, and anterior views (C 111.6 m); (13, 17) cranidium, SUI 146993, anterior and dorsal views (C $111.6 \mathrm{~m}) ;(\mathbf{1 6}, \mathbf{2 0}, \mathbf{2 4})$ cranidium, SUI 146994, dorsal, left lateral, and anterior views (G $26.6 \mathrm{~m}) ;(\mathbf{1 8})$ right librigena, SUI 146995, external view (G 26.6 m); (19, 22) right librigena, SUI 146996, external and internal view (C 111.6 m); (21) right librigena, SUI 146997, external view (G 26.6 m); (23) left librigena, SUI 146998, external view (G 27.0 m); (25) left librigena, SUI 146999, external view (C 111.6 m); (26, 29, 31) pygidium, SUI 147000, right lateral, posterior, and dorsal views (G $26.6 \mathrm{~m}) ;(\mathbf{2 7}, \mathbf{2 8 , 3 0})$ pygidium, SUI 147001, left lateral, posterior, and dorsal views $(\mathrm{C} 111.6 \mathrm{~m})$. Scale bars $=1 \mathrm{~mm}$. 


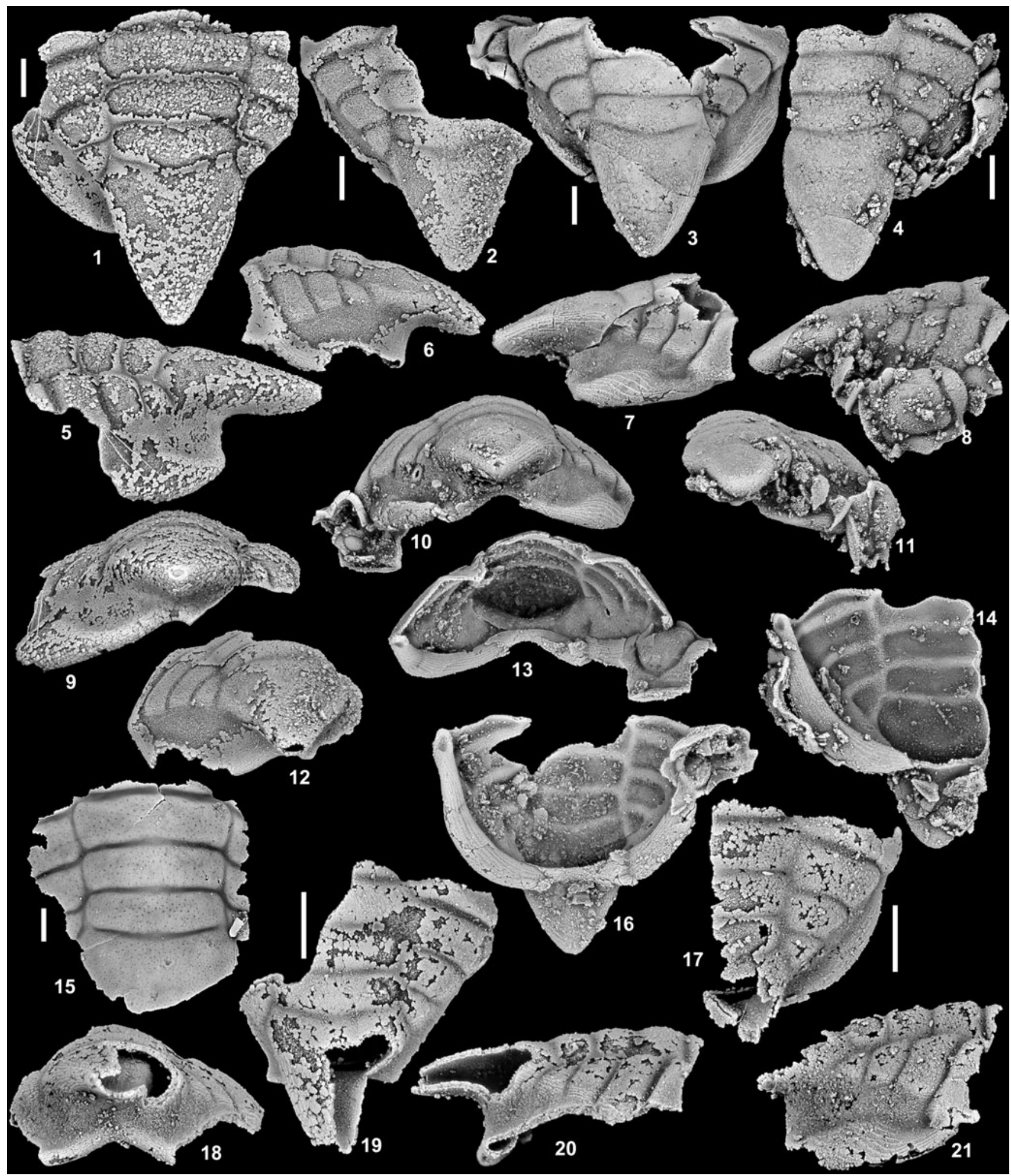

Figure 3. Gonioteloides monoceros Kobayashi, 1955, from Section C $111.6 \mathrm{~m}$, southern House Range, and Section G $26.6 \mathrm{~m}$ and $27.0 \mathrm{~m}$, southern Confusion Range, both Fillmore Formation, Ibex area, Millard County, western Utah, USA; and Section HC6 122.5 m, Garden City Formation, west side of Hillyard Canyon, Bear River Range, Franklin County, southeastern Idaho, USA (all upper Tremadocian; Stairsian; Bearriverops alsacharovi Zone). (1, 5, 9) Pygidium, SUI 147002, dorsal, left lateral, and posterior views (G 27.0 m); (2, 6, 12) pygidium, SUI 147003, dorsal, left lateral, and posterior views $(\mathrm{G} 26.6 \mathrm{~m}) ;(\mathbf{3 , 7 , 1 0 , 1 3 , 1 6})$ pygidium, SUI 134156, dorsal, right lateral, posterior, anterior, and ventral views (G $27.0 \mathrm{~m}) ;(\mathbf{4}, \mathbf{8}, \mathbf{1 1}, \mathbf{1 4})$ pygidium, SUI 147004, dorsal, right lateral, posterior, and ventral views (C 111.6 m); (15) pygidium, SUI 147005, dorsal view (HC6 122.5 m); (17, 21) pygidium, SUI 147006, dorsal and right lateral view (G $26.6 \mathrm{~m}) ;(\mathbf{1 8}-\mathbf{2 0})$ pygidium, SUI 147007, posterior, dorsal, and right lateral views (G $27.0 \mathrm{~m})$. Scale bars $=1 \mathrm{~mm}$. 
incised overall, but with deeper sections laterally on either side of portion conjoined with preglabellar furrow, in anterior view furrow strongly arched upward, in dorsal view furrow describes broadly open "M" shape; anterior border with anterior margin medially concave (dorsal view) in larger specimens (e.g., Fig. 2.1, 2.17), but gently convex to transverse in smaller specimens (e.g., Fig. 2.2); anterior border overall short (sag., exsag.) in dorsal view, with medial portion longest and length tapering abaxially, length (sag., measured on Fig. 2.2, 2.3, 2.16) 14.6\% (14.0-15.6\%) glabellar length (sag.), in anterior view border tall and of more equal length along course, with strong upward bow medially, in lateral view anterior border forms a short shelf that sits in front of cranidium, sculpture of fine ridges present on anterior face of border (e.g., Fig. 2.13); anterior fixigena subtriangular, strongly downturned from horizontal plane, set off from interocular fixigena by faint shallow furrow; interocular fixigena with adaxial margin less strongly laterally bowed than abaxial margin, broadest (tr.) opposite $\delta$, with maximum width (tr.) $32.3 \%$ (26.1-37.4\%) glabellar width (tr.), gently tapered (tr.) anteriorly and posteriorly; interocular fixigena with slight independent inflation, sitting below glabella in lateral view, palpebral lobe sitting in turn below interocular fixigena; palpebral lobe long, with length (exsag.) $73.4 \%$ (68.6-79.7\%) glabellar length (sag.), moderately broad, with width (tr.) opposite $\delta 32.4 \%$ (30.7-35.3\%) maximum width (tr.) of interocular fixigena, anterior and posterior tips of lobe narrower (tr.), lobe clearly set off from interocular fixigena by narrow, deeply incised palpebral furrow; posterior fixigena very short (exsag.), distal tip pinched out, extending laterally to about same distance or just beyond lateral extent of palpebral lobe; posterior border furrow moderately long (exsag.), slightly deeper medially, oriented sub-parallel to transverse axis, and curved forward; posterior border occupying majority of posterior projection (exsag.), with length (exsag.) at axial furrow 34.6\% (31.3-36.5\%) length (sag.) LO, border lengthened abaxially with maximum length (exsag.) achieved at distal tip, posterior margin of posterior border with proximal portion held nearly transverse, slight change in course at fulcrum so that margin is angled forward obliquely, distal tip forming rounded corner; posterior projection overall extends laterally just beyond palpebral lobes (e.g., Fig. 2.3), strongly downturned from horizontal plane (Fig. 2.11, 2.12); in lateral profile shape outlined by facial suture subrectangular, dorsoventrally tall; SO similar to axial furrows in depth and size, confluent with axial furrows, subtransverse to very gently posteriorly bowed; LO long (sag., exsag.) with maximum length (sag.) 23.7\% (20.8$25.9 \%$ ) glabellar length (sag), slightly tapered (exsag.) abaxially, posterior margin gently rounded, anterior margin more nearly transverse; doublure beneath LO extends to about midpoint of LO (sag., exsag.) (see Fig. 2.14, 2.15), anterior margin nearly transverse, posterior margin more strongly posteriorly bowed with narrow rim developed along posterior margin, surface smooth; dorsal surface of cranidium largely smooth except for raised lines on anterior border, which are especially prominent in anterior view and strongly bowed upward following upward curve of anterior border (Fig. 2.10, 2.13).
Rostral plate, hypostome, and thorax not recovered.

Librigena with field broad, smooth, slightly broader (tr.) posteriorly than anteriorly; lateral border broad (tr.), slightly tapered anteriorly (tr.), with sculpture of fine lines, on smaller specimen (Fig. 2.23) lines are more parallel to each other and occupy nearly the entire breadth and length of the lateral border, whereas on larger specimens the lines are less regularly positioned and are absent on the inner portion of the border near the genal angle (e.g., Fig. 2.18, 2.21); posterior border clearly developed, extending a short distance beyond genal angle, not as broad as lateral border, smooth; lateral border furrow broad, shallow, slightly broader at genal angle on larger specimens; posterior border furrow similar in breadth to lateral, but deeper; genal angle forming sharp, obtuse angular corner, with genal spine expressed as a small nubbin on larger specimens, spine longer and thorn-like on smaller specimens; eye very large, occupying nearly entire length of genal field, visual surface not fully preserved on any recovered specimens; eye socle expressed as narrow strip around base of eye on smaller specimens, but reduced on larger specimens, set off from visual surface of eye by narrow shallow furrow; eye socle furrow clearly incised, narrower and deeper than border furrow; anterior facial suture with section bounding field gently outwardly bowed and distal section straight, section bounding field longer than section along anterior projection, sections meet at $\sim 106^{\circ}$ angle before portion opposite distal section of anterior projection curves back (Fig. 2.19); posterior facial suture shorter than anterior suture, with section opposite field moderately outwardly bowed (Fig. 2.18) and much longer than that opposite posterior border, two sections of suture meet at $\sim 114^{\circ}$ angle (Fig. 2.19); anterior projection short (exsag; Fig. 2.19); doublure present beneath border and anterior projections, anterior portion more rounded and strongly curved upward toward inner surface of librigena, posterior portion more flattened, not reaching ventral expression of lateral border furrow, smooth.

Pygidial measurements were taken from specimens on Figures 2, 3, and, when necessary, from one side of pygidium to the mid-line, or an inferred mid-line, and then doubled to acquire a complete measurement across the entire sclerite. Pygidium subtrapezoidal (best observed in ventral view), overall wider (tr.) than long (sag., excluding posterior spine), with posterolateral corners rounded and bowed outward; in lateral profile pygidium dorsoventrally tall with portion from border to lateral margin of pleurae and post-axial spine forming "wall" on which main portion of pygidium is situated; lateral profile of pleural tips and anterior portion of posterior spine bowed with posterior portion of spine angled downward from horizontal plane; in dorsal view the distal pleural tips to tip of posterior spine describe a gentle "S" curve (Fig. 3.3); articulating half-ring apparently very short (sag., exsag.) (see Figs. 2.30, 3.1, 3.19), but not completely preserved on any one specimen, gently anteriorly bowed; axis very broad (tr.), with maximum width across first axial segment (tr.) $48.4 \%$ (45.3-51.4\%) pygidial width (tr.) (measured on Fig. 3.2, 3.3), composed of three clearly defined axial segments and large terminal piece extended into posterior spine; first three axial ring segments clearly expressed, with first two segments sub-rectangular in outline, third segment with posterior margin posteriorly bowed, sometimes describing a " $\mathrm{V}$ " shape (e.g., Fig. 3.3); length (sag.) of three axial segments nearly 
equal; length (sag.) of posterior spine about half total sagittal length of axis (excluding articulating half-ring); first axial segment widest (tr.), third segment narrowest (tr.), with axis waisted (tr.) at second ring furrow; terminal axial piece developed into broad, moderately long blade-like posterior spine, extended beyond posterior margin of pygidial border, spine tip bluntly rounded; ring furrows incised, short (sag., exsag.), slightly longer and shallower medially on some specimens (e.g., Fig. 3.3, 3.15); axial furrow narrow (tr.), moderately shallow, deeper at intersections with axial ring furrows, gently outwardly bowed around distal margins of first two axial segments, slightly less so around third segment; maximum width (tr.) of pleural region $\sim 60 \%$ width (tr.) of axis; first three pleural furrows deeply incised, with first furrow slightly longer (exsag.) than second and third, first furrow widest (tr.) with second and third progressively narrower (tr.); fourth furrow less clearly incised, much shorter (tr.), visible adjacent to posterior spine (see Fig. 3.2); first pleural furrow with main portion directed obliquely and distal tip curved around pleural tip, second pleural furrow with similar course to first, but with proximal tip curved into axial furrow at their intersection; third and fourth furrows generally obliquely directed; interpleural furrows not expressed; facet large, subtriangular, with short thorn-like projection developed at anterolateral corner (Fig. 3.7); anterior margin of first pleurae anterior bowed; pleurae with distal tips developed into short, blunt, lateral projections (see Fig. 3.7), together forming a linear ridge around pygidium; sculpture of raised lines present along lateral margins of spine and tips of pleurae and onto lateral margin of posterior spine; borders and furrows strongly flexed downward from horizontal plane forming a tall "wall" upon which main portion of pygidium sits; lateral border furrow broad, lenticular in dorsal view (Fig. 3.3), furrow narrowest anteriorly opposite first pleural band becoming progressively broader posteriorly in lateral view (e.g., Fig. 3.7), furrow deeper at intersection with first pleural furrow forming a depression, very faint, fine raised anastomosing lines present on anterior portion of border furrow (Fig. 3.7); lateral border strongly inflated, crescent shaped in dorsal view with anterior tip pinched (tr.), in lateral and posterior views medial portion much broader with adaxial margin describing a wave shape (Fig. 3.7) and abaxial margin more evenly arcuate, directed ventrolaterally (see Fig. 3.9); lateral border with sculpture of prominent raised lines, lines finer and more densely spaced on anterior portion of border; posterior border narrower (sag., exsag.) than median part of lateral border, largely obscured by posterior spine in dorsal view, medial portion strongly bowed upward from horizontal plane in posterior view (e.g., Fig. 3.9, 3.10, 3.13, 3.18) so that posterior border and posterior spine appear to just meet medially, pinching out posterior border (see Fig. 3.9), with sculpture of densely spaced fine raised lines similar to that on anterior portion of lateral border; doublure broad (tr., exsag.), less so sagittally, inner margin describing broad " $U$ " shape in ventral view, flexed upward toward ventral surface of pygidium (Fig. 3.13), terraced sculpture covering entire doublure (Fig. 3.9, 3.16), with lines less densely spaced on posterolateral portions; moderately large articulating socket present at anterolateral corner of doublure (Fig. 3.16).

Materials.-In addition to the holotype, assigned specimens SUI 134155, 134156, 146990-147007.
Ontogeny.-Glabella becomes increasingly pinched (tr.) opposite anterior portion of interocular fixigena (e.g., Fig. 2.17). The anterior border is more anteriorly bowed (dorsal view) and less strongly ventrally arched (anterior view) on smaller specimens, and becomes gently posteriorly bowed (dorsal view) and more strongly ventrally arched (anterior view) in larger specimens. Short, moderately thin genal spine present on smallest specimen (Fig. 2.23). Spine becomes continually reduced throughout ontogeny, so that on the largest specimens (Fig. 2.19) the spine reduced to a nubbin. A poorly differentiated fourth segment can be observed on smaller pygidia (Fig. 2.30). It is reduced throughout ontogeny and expressed on larger specimens only as a barely visible swollen area on the anterior portion of the terminal axial piece. Posterior spine increases in length throughout ontogeny. Orientation of posterior spine also changes throughout ontogeny, from being angled upward just above horizontal plane in smallest specimens (Fig. 2.27) and angled downward from horizontal plane as spine is lengthened (sag.) in larger specimens. There is a clear separation between the posterior border medially and the posterior spine on smaller specimens, but this separation decreases throughout ontogeny so that the two just meet medially on larger specimens. Lateral border furrow with anterior portion narrow (tr.) (in lateral view) and becoming broader throughout ontogeny.

Remarks.-Although Kobayashi's (1955) photographs of uncoated and unwhitened specimens of many taxa can be difficult to interpret, the morphology of Gonioteloides pygidia is so striking that it can be discerned fairly easily from his images. Together with Dean's (1989, pl. 27, figs. 4, 5) reillustration of the holotype, there is little doubt that they are conspecific with pygidia recovered from the Bearriverops alsacharovi Zone in the Ibex area. They share the expression of three axial rings, with the third ring furrow posteriorly bowed, and a broad-based, dorsoventrally flattened posterior spine of the same length that "droops" ventrally in lateral view. All other aspects of their morphology also match exactly.

Gonioteloides punctatus Kobayashi, 1955, apparently has not been commented upon since its proposal. It was based on a single large pygidium, which Kobayashi claimed was distinct from those he assigned to G. monoceros in various degrees of expression of furrows and minor dimensions of various features. He also (Kobayashi, 1955, p. 448) considered that it has a pitted, or punctate, surface, "as well as internally." His photos, however, reveal no obvious differences between the unique holotype of G. punctatus and the specimens assigned to G. monoceros. The posterior spine is the same relative length, and has the same posteroventral "droop." To the limited extent that there are any minor morphological differences, they may be due to the fact that the G. punctatus specimen is much larger. The "pitted" sculpture is impossible to assess from the published photographs, but no such morphology is present in any of the material described herein. We regard $G$. punctatus as a junior subjective synonym of G. monoceros.

Of the species described herein, G. monoceros is most similar to Gonioteloides n. sp. B, from the underlying Bearriverops deltaensis Zone. This slightly older species is known only from librigenae and pygidia (Fig. 9). The librigenae of Gonioteloides 
n. sp. B differ in having the short genal spine of smaller specimens running posterolaterally instead of slightly posterior medially (cf., Fig. 9.1, 9.2 with Fig. 2.3). The field is also clearly narrower. Pygidia are very similar, but those of Gonioteloides n. sp. B have a slightly shorter posterior spine with a broader, blunter, and more arcuate tip. In particular, the spine in Gonioteloides $\mathrm{n}$. sp. B does not "droop" ventrally in lateral profile as it does in all relevant specimens of G. monoceros.

Gonioteloides monoceros is next most similar to Gonioteloides $\mathrm{n}$. sp. A from Unnamed Zone One of Adrain et al. (2014a). The outline and dimensions of the pygidium, excluding the posterior spines, are very similar, although the pleural regions in Gonioteloides n. sp. A are markedly narrower. The pygidia are also similarly vaulted in posterior view, with the border describing an inverted "V" shape. Significant differences include lack of obvious expression of the fourth pleural furrow in Gonioteloides n. sp. A, longer (sag., exsag.) ring furrows with the third transverse and not bowed posteriorly, and, in particular, a much longer posterior spine, with a large post-axial keel running down its dorsal aspect. In G. monoceros, the lateral margins of the spine are laterally bowed, and the spine comes to a blunt posterior point. In Gonioteloides n. sp. A, the lateral margins are initially subparallel in large specimens, then converge strongly posteriorly to a sharp posterior point. A small pygidium of Gonioteloides n. sp. A (Fig. 8.13) shows faint axial nodes. Importantly, four seem to be present, including one on what seems to be the base of the spine, indicating that a fourth segment is present, despite the fourth pleural furrow not appearing to be expressed. Librigenae of the species are very similar, and in both, the genal spine is reduced to a blunt nubbin in the largest specimens. The main differences are that the lateral border is anteriorly broader in G. monoceros, the eye is much larger, and the field is considerably narrower. The cranidium of Gonioteloides $\mathrm{n}$. $\mathrm{sp}$. A is known only from a fragmentary and relatively small specimen (Fig. 7.1, 7.4, 7.8). It shows a similar degree of vaulting as those of G. monoceros, along with similar distinct waisting behind the anterior edge of the palpebral lobe. Its palpebral lobe is wider and shorter, matching the smaller eye. The specimen is otherwise too incomplete for detailed comparison.

The remaining member of the highly vaulted group, $G$. moffitti $\mathrm{n}$. sp., is the least similar to G. monoceros (not surprising because it is the oldest known species, whereas G. monoceros is one of the two youngest). The anterior border of G. monoceros looks relatively short (sag., exsag.) in dorsal view, whereas that of G. moffitti n. sp. is clearly relatively longer at any position. Conversely, the border is taller in anterior view in G. monoceros than in G. moffitti n. sp., while its transverse arc is more muted. The preglabellar field is present medially in all specimens of $G$. moffitti n. sp., but absent in G. monoceros. The frontal areas are larger in G. moffitti n. sp., the anterior edge of the palpebral lobe is farther away from the glabella, and the palpebral lobe is much shorter (exsag.). The posterior end of the palpebral lobe is set much farther from the glabella in G. moffitti n. sp., and the posterior projection is much larger, with a subtriangular expanse of fixigena, and wider. The glabella is of similar shape, but it is much more subtly waisted behind the anterior edge of the palpebral lobe. Librigenae are quite similar, but those of G. moffitti n. sp. have smaller eyes, broader fields, narrower lateral borders, and large specimens retain a fairly long genal spine. Pygidia of the species are strikingly different. In contrast with the broad and spatulate spine of G. monoceros, that of G. moffitti n. sp. is posteriorly narrow and nearly cylindrical. In lateral view, it bends dorsally instead of "drooping" ventrally. Only the first two ring furrows are well expressed in most specimens of G. moffitti n. sp., although a third is sometimes discernible (e.g., Fig. 6.5). The axis is narrower, and does not expand laterally at the base of the spine. The pleural tips in G. moffitti n. sp. form a much more subdued ridge, and the doublure is narrower in ventral view.

\section{Gonioteloides moffitti new species Figures 4-6}

2014a Gonioteloides sp. nov. 1; Adrain et al., p. 176, fig. 8C, G.

Holotype.-Cranidium, SUI 134078 (Fig. 4.3, 4.7, 4.11, 4.15, 4.16) from Section MME $49.8 \mathrm{~m}$, Fillmore Formation (upper Tremadocian; Stairsian; Rossaspis leboni Zone), Middle Mountain, Ibex area, Millard County, western Utah.

Diagnosis.—Anterior border inflated and long (sag., exsag.) in dorsal view and strongly transversely arched in anterior view; preglabellar field present medially; frontal areas large, interocular fixigena broad, and posterior projections broad with subtriangular posterior fixigena; glabella with muted but discernible waisting behind anterior edge of palpebral lobe; palpebral lobe short; librigenae with the longest genal spines of any species, retained as fairly long spine in large specimens; eye small and field broad; lateral border narrow, slightly broader posteriorly; pygidium with only first two axial rings well defined, third ring furrow faint to obscure; pleural tips forming only weak amalgamated ridge; interpleural furrows better expressed than in any other species; posterior spine broad at base, but narrowed to a nearly cylindrical form posteriorly, posterior part turned dorsally in lateral view.

Occurrence.-Section MME 36.4 and $49.8 \mathrm{~m}$, Fillmore Formation (upper Tremadocian; Stairsian; Rossaspis leboni Zone), Middle Mountain, Ibex area, Millard County, western Utah.

Description.-Cranidium with strong dorsoventral inflation, with sagittal length $88 \%$ (83.3-92.9\%) width across $\delta$, sagittal length $81.8 \%$ (77.8-88.5\%) width across $\gamma$; glabella "thumb" shaped, with slight lateral (tr.) expansion opposite posterior end of palpebral lobe and weak constriction (tr.) just behind anterior end of palpebral lobe, with length (sag.) $108.7 \%$ (102.2-114.2\%) maximum width (tr.), with strong independent dorsoventral inflation; lateral glabellar furrows not expressed; preglabellar furrow deep narrow, gently arched anteriorly, smoothly confluent with axial furrow, which is similarly deep, but slightly broader (tr.); very thin strip of preglabellar field present between anterior border furrow and preglabellar furrow medially so that the two furrows are not confluent; anterior border furrow describing broad shallow " $\mathrm{M}$ " moderately deep and long (sag., exsag.) along entire course, with distal tips shorter (exsag.), in anterior view furrow strongly bowed upward; anterior border forming long 


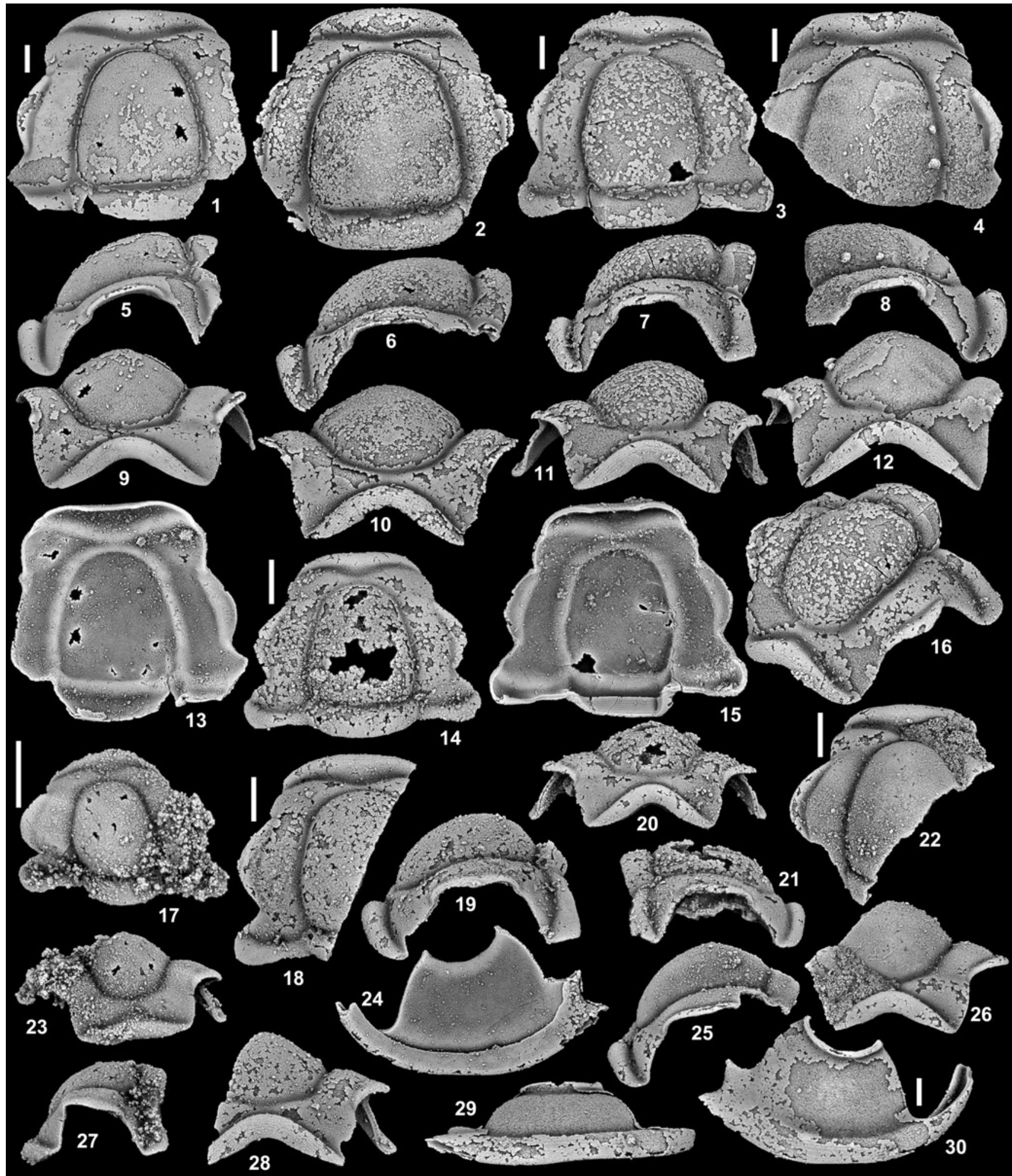

Figure 4. Gonioteloides moffitti n. sp. from Section MME $49.8 \mathrm{~m}$, Fillmore Formation (upper Tremadocian; Stairsian; Rossaspis leboni Zone), Middle Mountain, Ibex area, Millard County, western Utah, USA. (1, 5, 9, 13) Cranidium, SUI 147008, dorsal, left lateral, anterior, and ventral views; $(\mathbf{2 , 6 , 1 0})$ cranidium, SUI 147009, dorsal, left lateral, and anterior views; $(\mathbf{3 , 7 , 1 1 , 1 5}, \mathbf{1 6})$ cranidium, holotype, SUI 134078, dorsal, left lateral, anterior, ventral, and oblique views; $(\mathbf{4 , 8 , 1 2})$ cranidium, SUI 147010, dorsal, right lateral, and anterior views; (14, 20,21) cranidium, SUI 147011, dorsal, anterior, and right lateral views; (17, 23, 27) cranidium, SUI 147012, dorsal, anterior, and left lateral views; $(\mathbf{1 8 , 1 9 , 2 8})$ cranidium, SUI 147013, dorsal, left lateral, and anterior views; $(\mathbf{2 2}, \mathbf{2 5}, \mathbf{2 6}) \mathrm{cranidium,} \mathrm{SUI} \mathrm{147014,} \mathrm{dorsal,} \mathrm{left}$ lateral, and anterior views; $(\mathbf{2 4}, \mathbf{2 9}, \mathbf{3 0})$ right librigena, SUI 147015, internal, ventrolateral, and external views. Scale bars $=1 \mathrm{~mm}$ 


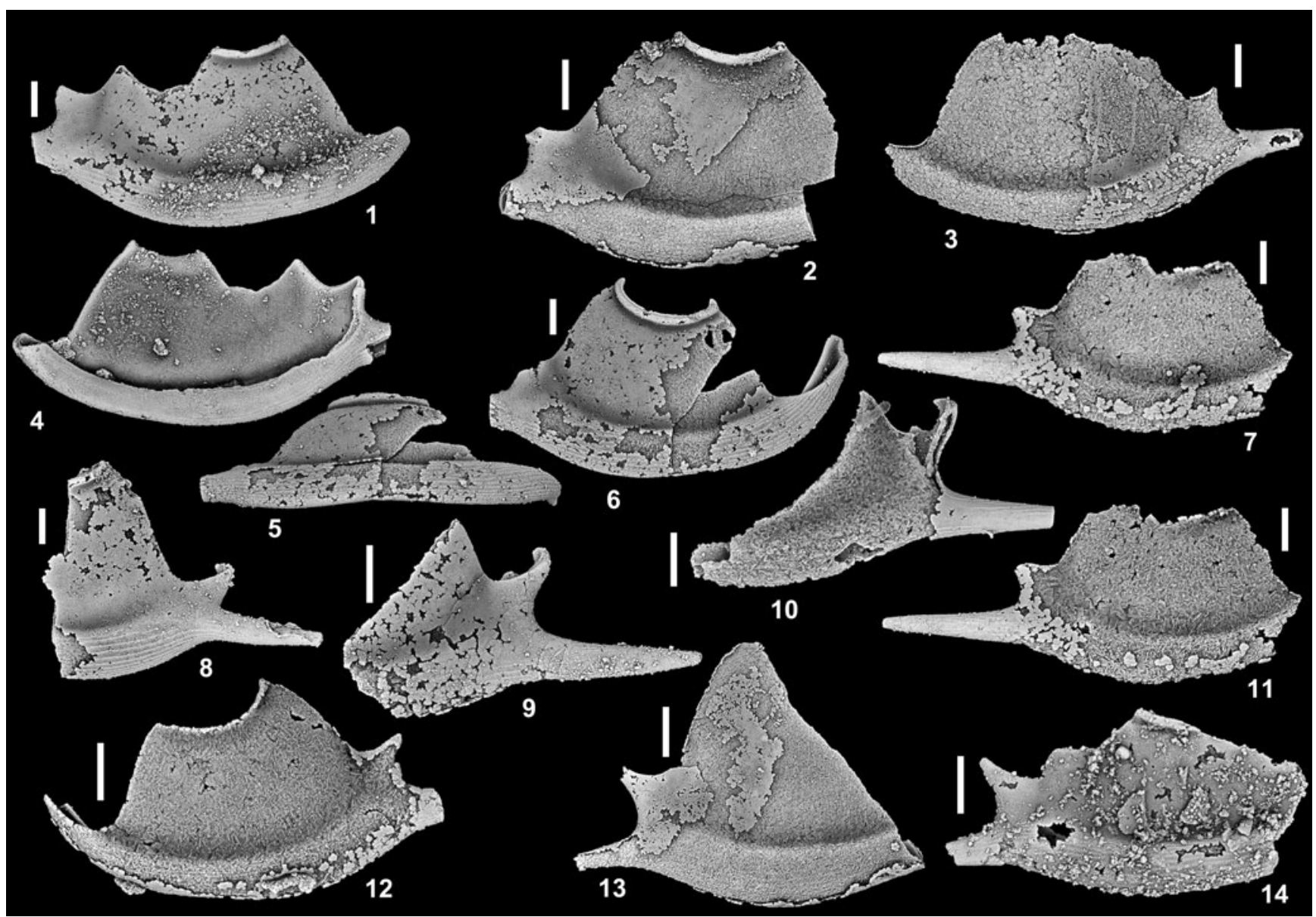

Figure 5. Gonioteloides moffitti $\mathrm{n}$. sp. from Section MME $36.4 \mathrm{~m}$ (where indicated) and $49.8 \mathrm{~m}$ (except where indicated), Fillmore Formation (upper Tremadocian; Stairsian; Rossaspis leboni Zone), Middle Mountain, Ibex area, Millard County, western Utah, USA. (1, 4) Right librigena, SUI 147016, external and internal views: (2) right librigena, SUI 147017, external view; (3) left librigena, SUI 147018, external view; (5, 6) right librigena, SUI 147019, ventrolateral and external views; (7) right librigena, SUI 147020, external view); (8) left librigena, SUI 147021, external view; (9) left librigena, SUI 147022, external view; (10) left librigena, SUI 147023, external view; (11) right librigena, SUI 147024, external view; (12) left librigena, SUI 147025, external view; (13) right librigena, SUI 147026, external view; (14) right librigena, SUI 147027, external view (MME $36.4 \mathrm{~m}$ ). Scale bars $=2 \mathrm{~mm}(\mathbf{2 , 3 , 1 3})$ or $1 \mathrm{~mm}$ (all others).

(sag.) strongly inflated rolled rim, longest medially with length (sag.) $16.9 \%$ (15.5-18.3\%) glabellar length (sag.), pinched (exsag.) out laterally with distal tip recurved posteriorly, anterior margin with nearly transverse median sector and outwardly bowed lateral sectors; border situated in front of preglabellar field in lateral view; in anterior view, border strongly arched upward medially, height more uniform across border and with less dramatically tapered distal portions than appearance in dorsal view; sculpture of faint, fine raised lines present on border, lines follow curve of border; space outlined by facial suture in lateral profile dorsoventrally tall trapezoidal shaped, generally with anterior and posterior portions even, but sometimes more sloped anteriorly (e.g., Fig. 4.5); frontal area large, subtriangular in anterior view, strongly downturned from horizontal plane; fixigena generally broad (tr.), with anterior fixigena set off from interocular fixigena by very shallow furrow, just barely visible on ventral surface as very faint obliquely directed ridge (Fig. 4.13); interocular fixigena broad, slightly wider (tr.) opposite $\delta$, with width at this point $28.8 \%$ (23.8-31.6\%) maximum glabellar width (tr.); posterior fixigena large, subtriangular, long (exsag.); palpebral furrow shallower than other cranidial furrows, medial sector widest (tr.) with distal tips pinched (tr.), gently bowed outward; palpebral lobe forming narrow crescent, short with length $61.6 \%(60.3-62.9 \%)$ glabellar length (sag.), maximum width (tr.) $9.0 \%$ (7.6-10.4\%) glabellar width (tr.), outer margin unevenly arcuate so that portion anterior to $\delta$ is longer and directed more obliquely than rear section; posterior projection overall long (exsag.), in dorsal view extended short distance beyond lateral extent of palpebral lobe and appearing narrow (tr.) due to strong downward flexure (Fig. 4.11); posterior border furrow moderately long (exsag.), distinct, distal section appears angled forward due to strong downward flexure of posterior projection, furrow terminated abruptly just before reaching facial suture (Fig. 4.16); posterior border shortest (exsag.) adjacent to axial furrow with length about half that of LO, longer abaxially with distal portion curved forward; SO deep, long (sag., exsag.), transverse, with distal sections curved forward around posterolateral corners of glabella, smoothly confluent with axial furrows; LO long (sag., exsag.) with length (sag.) $21.1 \%$ (19.2-23.5\%) glabellar length (sag.), main medial portion subtransverse with distal tips behind posterolateral corners of glabella curved forward; doublure present beneath LO, long (sag., exsag.) across majority of 


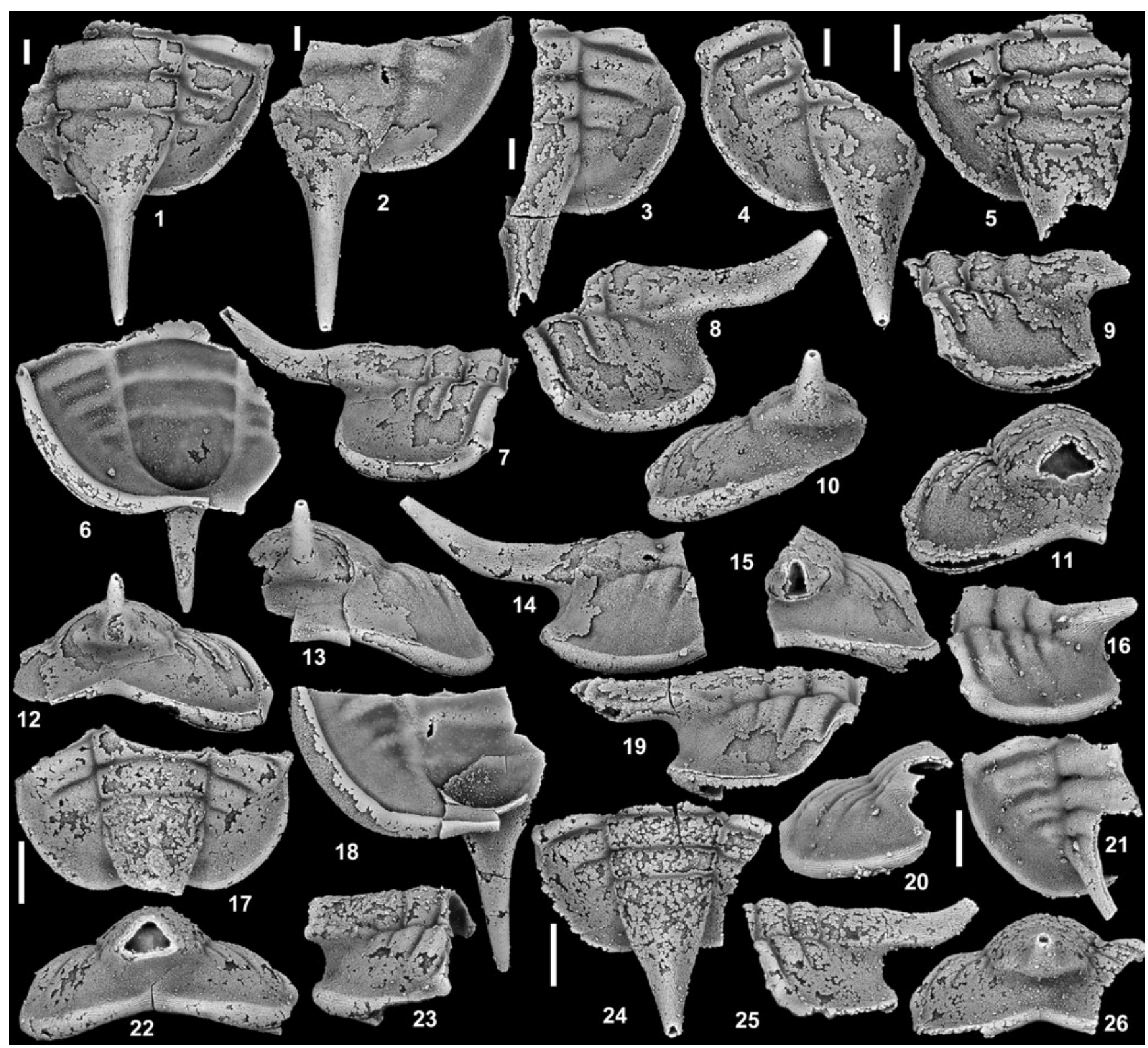

Figure 6. Gonioteloides moffitti n. sp. from Section MME $36.4 \mathrm{~m}$ (where indicated) and $49.8 \mathrm{~m}$ (except where indicated), Fillmore Formation (upper Tremadocian Stairsian; Rossaspis leboni Zone), Middle Mountain, Ibex area, Millard County, western Utah, USA. (1, 6, 7, 12) Pygidium, SUI 134079, dorsal, ventral, right lateral, and posterior views; $(\mathbf{2 , 1 3 , 1 4 , 1 8})$ pygidium, SUI 147028, dorsal, posterior, right lateral, and ventral views; $(\mathbf{3 , 1 5}, \mathbf{1 9})$ pygidium, SUI 147029, dorsal, posterior, and right lateral views; $(\mathbf{4 , 8 , 1 0})$ pygidium, SUI 147030 , dorsal, left lateral, and posterior views; $(\mathbf{5 , 9}, \mathbf{1 1})$ pygidium, SUI 147031 , dorsal, left lateral, and posterior views $(\mathbf{1 6}, \mathbf{2 0}, \mathbf{2 1})$ pygidium, SUI 147032, left lateral, posterior, and dorsal views (MME $36.4 \mathrm{~m}) ;(\mathbf{1 7}, \mathbf{2 2}, \mathbf{2 3})$ pygidium, SUI 147033, dorsal, posterior, and right lateral views; (24-26) pygidium, SUI 147034, dorsal, left lateral, and posterior views. Scale bars $=1 \mathrm{~mm}$.

width, with only very distal tips pinched (exsag.), prominent sculpture of transverse raised lines present; ventral margin of posterior border with narrow articulating groove present along proximal half of posterior margin, distal half forming very narrow rolled rim terminating in micro-spike (Fig. 4.15).

Hypostome, rostral plate, and thoracic segments not recovered.

Librigena with eye very small, occupying about half the length of the field, with visual surface not preserved on any recovered specimens; wide, prominent rim-like socle present, sitting above field; socle separated from field by distinct broad socle furrow that is deepest just below socle and becomes progressively shallower towards field; field broad, tall with strong dorsoventral inflation, apparently smooth (surface very incompletely preserved on most specimens); anterior facial suture very long, gently sinuous opposite field with portion below eye very gently convex and becoming concave toward border furrow, strong change in course at intersection with border furrow making a nearly $90^{\circ}$ bend across border furrow, bend describing rounded curve; portion of anterior facial suture along anterior projection long, moderately concave; posterior facial suture much shorter than anterior, with portion opposite field slightly more strongly convex, forming nearly $90^{\circ}$ concave curve across posterior border furrow; lateral border furrow 
shallow, marking distinct change in slope between field and border; lateral border narrow (tr.) (compare with G. monoceros), slightly wider posteriorly, external margin (along with posterior projection) describing nearly evenly arcuate curve (compare with G. monoceros), course of curve is disrupted at intersection with genal spine, which is straight along both external and internal margins and terminates in a point; anterior projection relatively long (Figs. 4.30, 5.6), with length $\sim 80 \%$ that of anterior facial suture across margin of field; genal spine long (even on larger specimens), tapered evenly along length to a point forming overall narrow spine; posterior border furrow shallow to effaced; intersection of lateral and posterior border furrows, where present, forming an obtuse angle, confluent with short depression at base of genal spine and forming a "Y" shape at their intersection (see Fig. 5.1); posterior border not well developed and not extending far beyond genal angle, terminating in an abaxial point (Fig. 5.11); angle between genal spine and posterior border slightly acute, with slight variation, smoothly rounded; sculpture of fine raised lines present along anterior projection, lateral border, and genal spine, also present along lateral face of posterior border; doublure present under lateral and posterior borders and anterior projection (Figs. 4.24, 5.4), portion beneath lateral border extending inward to inflection point marked by lateral border furrow, portion below posterior border not completely preserved on any recovered specimens, but present, inner margin of doublure describing apparently evenly arcuate curve, sculpture of fine raised lines present along outer margin of doublure beneath lateral border, with lines continuing onto doublure beneath genal angle, lines appear to be present onto doublure beneath posterior border, but difficult to determine extent of this sculpture on best-preserved specimens.

Pygidium subtrapezoidal in outline (excluding posterior spine), with maximum width (tr.) about twice length (sag. excluding spine); posterior margin with medial portion deflected anteriorly, but obscured by posterior spine in dorsal view; articulating half ring short (sag.) with length (sag.) about half length (sag.) of first axial segment (Fig. 6.5); articulating furrow deeply incised; axis with three axial rings and prominent posterior spine, gently tapered (tr.) posteriorly with width (tr.) of third segment $\sim 82 \%$ width (tr.) of first segment; second and third axial segments progressively slightly shorter (sag., exsag.) than first segment; in lateral profile, first and second segments with slightly stronger independent inflation than third segment; first two ring furrows clearly expressed, with third less so to nearly effaced (especially on larger specimens); morphology of first two furrows (and third furrow when expressed) consists of deeper section adjacent to axial furrow and shallower medial section, this morphology is more pronounced on smaller specimens where section adjacent to axial furrow is much deeper and slit-like (e.g., Fig. 6.21); posterior spine long (sag.), extending far beyond posterior margin of pygidium, with length of spine present beyond posterior pygidial margin $\sim 80 \%$ of pygidial length (sag., excluding articulating half-ring); posterior spine broad at base with subtriangular cross-section (Fig. 6.22), strongly tapered (tr.) posteriorly, becoming much narrower and cylindrical at distal tip; proximal portion of posterior spine held nearly parallel to horizontal plane and slight dorsal swelling (best observed in lateral profile), distal portion strongly recurved upward from horizontal plane in lateral view (e.g., Fig. 6.7,
6.14), very weak dorsal keel developed, expressed on some specimens as shallow depression present on proximal portion of spine along lateral face with depression extending farther along spine (nearly to distal tip) (e.g., Fig. 6.8), and with prominent swollen area developed at base of spine along lower portion of lateral face, almost ridge-like and continuing along ventral edge of lateral face on some specimens (e.g., Fig. 6.8); dorsal surfaces of posterior spine covered with closely spaced raised lines, lines arranged in a linear to chevron pattern along length of spine in dorsal view; on ventral surface, lines present along lateral margins of proximal portion of spine, outlining a median triangular depression (Fig. 6.18), with distal portion of ventral surface of posterior spine smooth; anterior margin of pygidium with small anteriorly directed bump at intersection with axial furrow, larger and broader anterior bow at fulcrum, portion distal to fulcrum sloped posterolaterally; anterolateral corner of pygidium developed into prominent knob-like anterolaterally directed process (Fig. 6.4, 6.21); pleural region with maximum width (tr.) 58\% width (tr.) of first axial segment; pleural tips developed into very weak rim, with portion of pygidium distal to pleural tips strongly downturned from horizontal plane, forming tall sloping "wall;" upper portion of pygidium bound by weak rim not overhanging "wall" sector; relatively broad strip of "wall" present posteriorly, separating posterior spine and posterior border, obscured in dorsal view by posterior spine; pleural furrows well developed, with interpleural furrows much less well developed, but visible on all specimens; first pleural furrow deep and longest (exsag.) of three, slightly shorter adjacent to axial furrow, nearly straight, directed posterolaterally; second pleural furrow shorter (exsag.) than first and not as wide (tr.), with portion directly adjacent to axial furrow deflected posteriorly, but overall directed posterolaterally parallel to first pleural furrow; third pleural furrow much shorter (exsag.) and narrower (tr.), very faint on some specimens; interpleural furrows very shallow, with third difficult to discern on some specimens; lateral and posterior borders narrow, inflated, confluent with anterior band of first segment forming rim around pygidial margin (e.g., Fig. 6.8); border gently bowed upward in posterior view creating distinct peak medially (Fig. 6.26); border with sculpture of fine, densely spaced, raised lines arranged roughly parallel to pygidial margin; doublure present beneath lateral and posterior borders, generally narrow, but broader beneath lateral and posterolateral pygidial margins, much shorter (sag.) medially with posterior margin deflected anteriorly (Fig. 6.6); portion of doublure beneath anterolateral portion of lateral border pinched (tr.) with small deep pit present at anterolateral tip.

\section{Etymology.-After John Moffitt.}

Materials. - In addition to the holotype, assigned specimens SUI 134079, 147008-147034.

Ontogeny.-One small cranidium was recovered (Fig. 4.17, $4.23,4.27)$. The anterior margin of anterior border is bowed forward along its entire course on the smallest specimen; the medial section becomes less bowed to nearly transverse throughout ontogeny. In anterior view, the posterior margin of the anterior border is nearly transverse and becomes much 
more strongly upwardly arched throughout ontogeny. The palpebral furrow is very shallow on the smallest specimen, becoming more deeply incised. SO and LO possess a medial sector that is strongly posteriorly bowed, becoming more transverse throughout ontogeny. With respect to the pygidium, interpleural furrows are clearly visible on one smaller specimen (Fig. 6.21), but shallower on larger specimens. The posterior spine lengthens and dorsoventral inflation increases throughout ontogeny.

Remarks.-Gonioteloides moffitti n. sp. is the oldest known species. It is compared with the type species above. It is not very similar to any other species, but the closest comparison is clearly the next youngest, Gonioteloides n. sp. A from the overlying Unnamed Zone One of Adrain et al. (2014a). Cranidia are difficult to compare because that of Gonioteloides n. sp. A is known from only a single fragmentary specimen. Nevertheless, it clearly has a larger palpebral lobe than that of G. moffitti n. sp. Librigenae are quite similar, but those of Gonioteloides n. sp. A have larger eyes and reduce the genal spine to a blunt nubbin in large specimens. Pygidia are similar in that they have longer posterior spines than any other species. In addition, they are the only species with a dorsal keel on the spine, although it is much better developed in Gonioteloides n. sp. A. The spines of both species have similar curvature in lateral view, trending posteroventrally immediately in front of the base, then arced posterodorsally toward the tip.

\section{Gonioteloides new species A} Figures 7, 8

2014a Gonioteloides sp. nov. A; Adrain et al., p. 176, fig. 9D.

Occurrence.-Section G 60.7 m, Fillmore Formation (upper Tremadocian; Stairsian; Unnamed Zone 1 of Adrain et al, 2014a), southern Confusion Range, Ibex area, Millard County, western Utah.

Materials.-Assigned specimens SUI 134109, 147035147046

Remarks.-Gonioteloides n. sp. A is compared with other members of the vaulted species group above. It is unique in the length, robustness, and complex morphology of its pygidial posterior spine. The spine features flattened lateral parts, atop which is positioned an elongate keel that is wider anteriorly and connects to the terminal piece. The tip of the spine rapidly narrows and comes to a sharp posterior point. The spine is covered with arcuate raised lines, both dorsally and ventrally. The ventral aspect has an elongate concavity on the anterior portion. Enough pygidia were recovered to give some idea of ontogenetic change. Smaller pygidia (Fig. 8.13) have a much shorter spine shaped like an elongate "V" in dorsal view. The spine becomes progressively longer and more robust in larger specimens. It is unfortunate that only a single partial cranidium was recovered because the species is highly distinctive and otherwise well enough known to formally name.
Gonioteloides new species B

Figure 9

2014a Gonioteloides sp. nov. B; Adrain et al., p. 179, fig. 11H.

Occurrence.-Section MME $84.0 \mathrm{~m}$, Middle Mountain, and Section AAA $79.5 \mathrm{~m}$, northern House Range, both Fillmore Formation (upper Tremadocian; Stairsian; Bearriverops deltaensis Zone), Ibex area, Millard County, western Utah.

Materials.-Assigned specimens SUI 134147, 147047147051

Remarks._-Of the species illustrated herein, Gonioteloides n. sp. B is most similar to G. monoceros, with which it is compared above. It is also quite similar to the pygidium from the Manitou Formation of Colorado illustrated by Berg and Ross (1959, p. 117, pl. 21, figs. 8, 9) as Gonioteloides sp. cf. G. monoceros Kobayashi. In dorsal view, the main difference is that the Colorado specimen has a slightly longer posterior spine, somewhat intermediate in length between that of Gonioteloides n. sp. B and G. monoceros. In lateral view, the spine of the Colorado specimen has a slight ventral "droop," similar to G. monoceros. Pygidia of Gonioteloides n. sp. B are different in this respect because in lateral view the spines are nearly straight, with no marked "droop."

Gonioteloides pankowskii new species Figures 10-14, 15.6, 15.8, 15.9

1997 Proetide A; Lee and Chatterton, p. 434, fig. 2.12, 2.13 (only; illustrated protaspids of fig. 2.1-2.11, 2.14 are of uncertain affinity).

2014a Gonioteloides sp. nov. 2; Adrain et al., p. 179, fig. 10C, F.

Holotype.-Pygidium, SUI 147076 (Fig. 12.1, 12.4, 12.7, 12.8, 12.11), from Section MME 75.5 m, Fillmore Formation (upper Tremadocian; Stairsian; Bearriverops loganensis Zone), Middle Mountain, Ibex area, Millard County, western Utah.

Diagnosis. - Cranidium only weakly inflated; eyes very large and palpebral lobes very long, occupying as much as four-fifths of glabellar length; cranidial posterior projections strap-like, wide (tr.), and set almost directly transversely; posterior border furrow not expressed on librigena in most specimens; librigena with short, thorn-like genal spine retained in specimens of all sizes; lateral border of similar width all along course; pygidium with four segments, but no terminal piece; "wall" low and pygidium not strongly dorsally vaulted; posterior projection lobate, flat, and short (sag.), extended only a short distance posteriorly from posterior margin of border.

Occurrence.-Section MME $75.5 \mathrm{~m}$ and 75.0T m, Fillmore Formation, Middle Mountain, Ibex area, Millard County, western Utah, and Section HC5 $106.7 \mathrm{~m}$, east side of Hillyard Canyon, Section HC6 88.3 and Section HC6 89.5, both west side of Hillyard Canyon; Section FB7 102.1, Franklin Basin, 


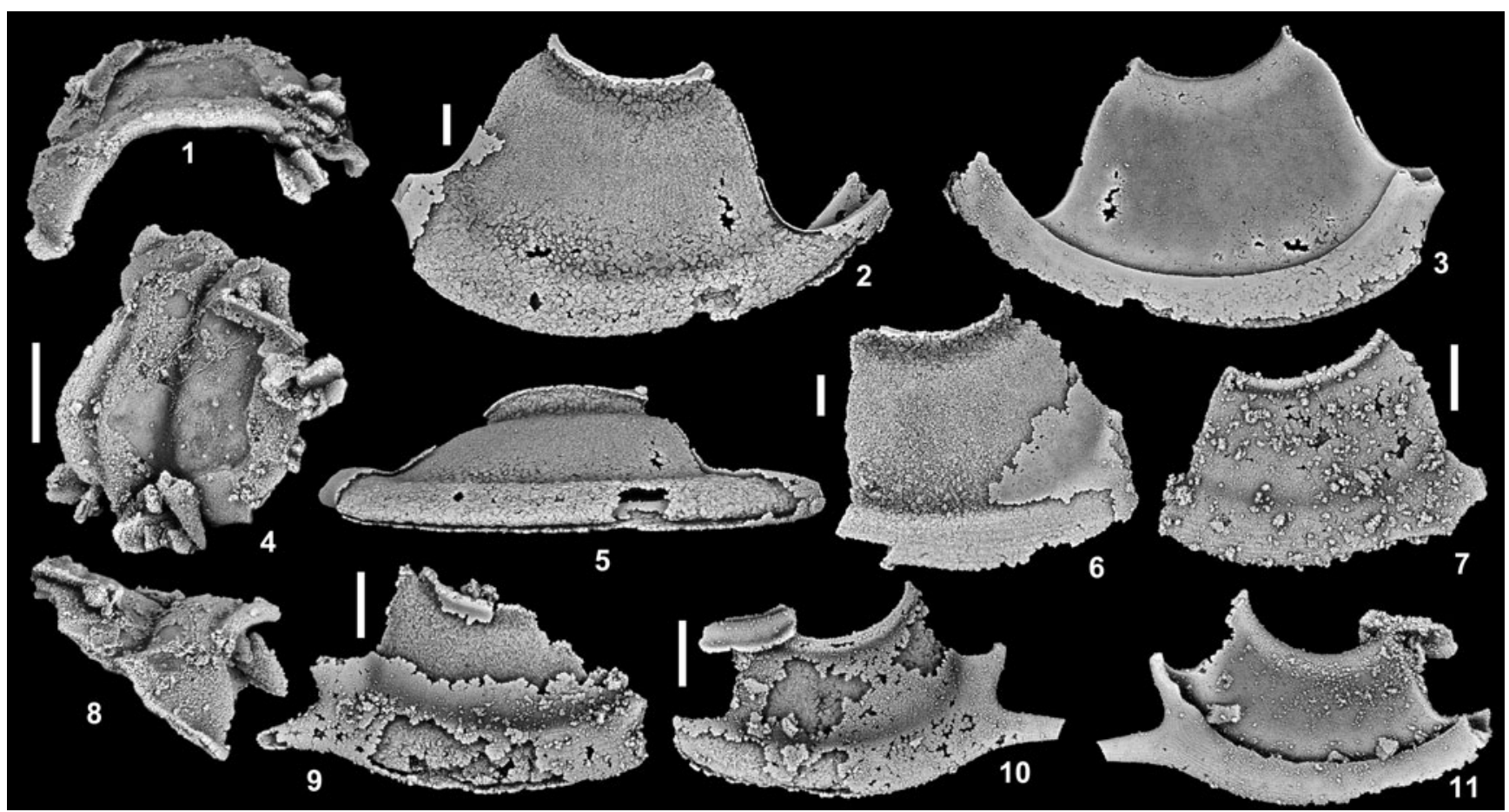

Figure 7. Gonioteloides n. sp. A from Section MME 60.7 m, Fillmore Formation (upper Tremadocian; Stairsian; Unnamed Zone 1), Middle Mountain, Ibex area, Millard County, western Utah, USA. (1, 4, 8) Cranidium, SUI 147035, left lateral, dorsal, and anterior views; $(\mathbf{2 , 3 , 5})$ right librigena, SUI 147036, external, internal, and ventrolateral views; (6) left librigena, SUI 147037, external view; (7) left librigena, SUI 147038, external view; (9) right librigena, SUI 147039, external view; $(\mathbf{1 0}, 11)$ left librigena, SUI 147040, external and internal views. Scale bars $=1 \mathrm{~mm}$.

all Garden City Formation, Bear River Range, Franklin County, southeastern Idaho (all upper Tremadocian; Stairsian; Bearriverops loganensis Zone).

Description.-Cranidial measurements were made on the largest specimens of Figures 10 and 13. Cranidium with weak dorsoventral inflation; sagittal length $78.1 \%$ (70.2-85.2\%) width across $\delta$, sagittal length $112.5 \%$ (99.1-123.0\%) width across $\gamma$, sagittal length $100.3 \%$ (99.7-100.8\%) width across $\epsilon$; glabella elongate, with general subtriangular outline, anterior margin strongly rounded, lateral margins with slight expansion (tr.) at point opposite $\delta$ and slight constriction (tr.) just behind point opposite anterior tip of palpebral lobe, overall more strongly tapered (tr.) forward than G. monoceros or G. moffitti n. sp., length (sag.) $114.2 \%$ (107.2-126.3\%) width (tr.) across posterolateral corners, with width (tr.) across posterolateral corners $156.4 \% \quad(143.5-169.9 \%)$ that at anterolateral corner of glabella; glabella smooth, with lateral furrows effaced; preglabellar furrow short (sag., exsag.), moderately deep, bowed anteriorly, smoothly confluent with axial furrows; preglabellar field largely pinched out medially (especially on larger specimens), with very thin strip present medially on some (generally smaller) specimens; anterior border furrow and preglabellar furrow mostly separated or just barely merged medially on some specimens; anterior border very short (sag., exsag.), length (sag.) 12.6\% (11.4-13.9\%) that of glabella, with anterior margin subtransverse to very gently convex, posterior margin generally following similar outline, but with gentle posterior bow medially, longest sagittally with lateral portions progressively shorter (exsag.) so that distal tips appear pinched out at intersection with facial suture; in anterior view, dorsal margin of border gently bowed upward (compare with G. monoceros), ventral margin less strongly bowed; border weakly inflated, shelf-like extending in front of cranidium; fixigena overall very broad (tr.); anterior fixigena large (tr., exsag.), flattened, gently downturned from horizontal plane; interocular fixigena very broad (tr.), with width at $\delta 43.5 \%(39.8-48.5 \%)$ glabellar width (tr. at posterolateral corners), abaxial margin strongly bowed outward following curve of palpebral lobe, anterior margin demarcated by shallow transverse furrow, visible ventrally as raised ridge (Fig. 10.3); posterior fixigena forming short (exsag.), wide (tr.), slightly sinuous strip, held subparallel to transverse axis, extended laterally well beyond palpebral lobe; palpebral furrow moderately incised along majority of course, much shallower at anterior and posterior tips, following curve of palpebral lobe; palpebral lobe very long with length $76.2 \%$ $(73.2-79.6 \%)$ of glabella (sag.), width (tr.) at $\delta 24.4 \%(19.2-$ $27.3 \%$ ) that of interocular fixigena at same point, strongly bowed outward, extended posteriorly, posterior tip strongly pinched and directed obliquely (e.g., Fig. 13.4); axial furrows deeply incised, with slightly deeper and broader (tr.) sections opposite $\delta ;$ in lateral profile facial suture outlines dorsoventrally short subrectangular shape; posterior projections strap-like, wide (tr.), extended well beyond lateral extent of palpebral lobe, with distal termination rounded and composed entirely of posterior border, oriented subparallel to transverse axis; posterior border furrow long (exsag.), shallow adjacent to axial furrow and at distal tip, deeper section medially behind posterior margin of palpebral lobe, distal tip 


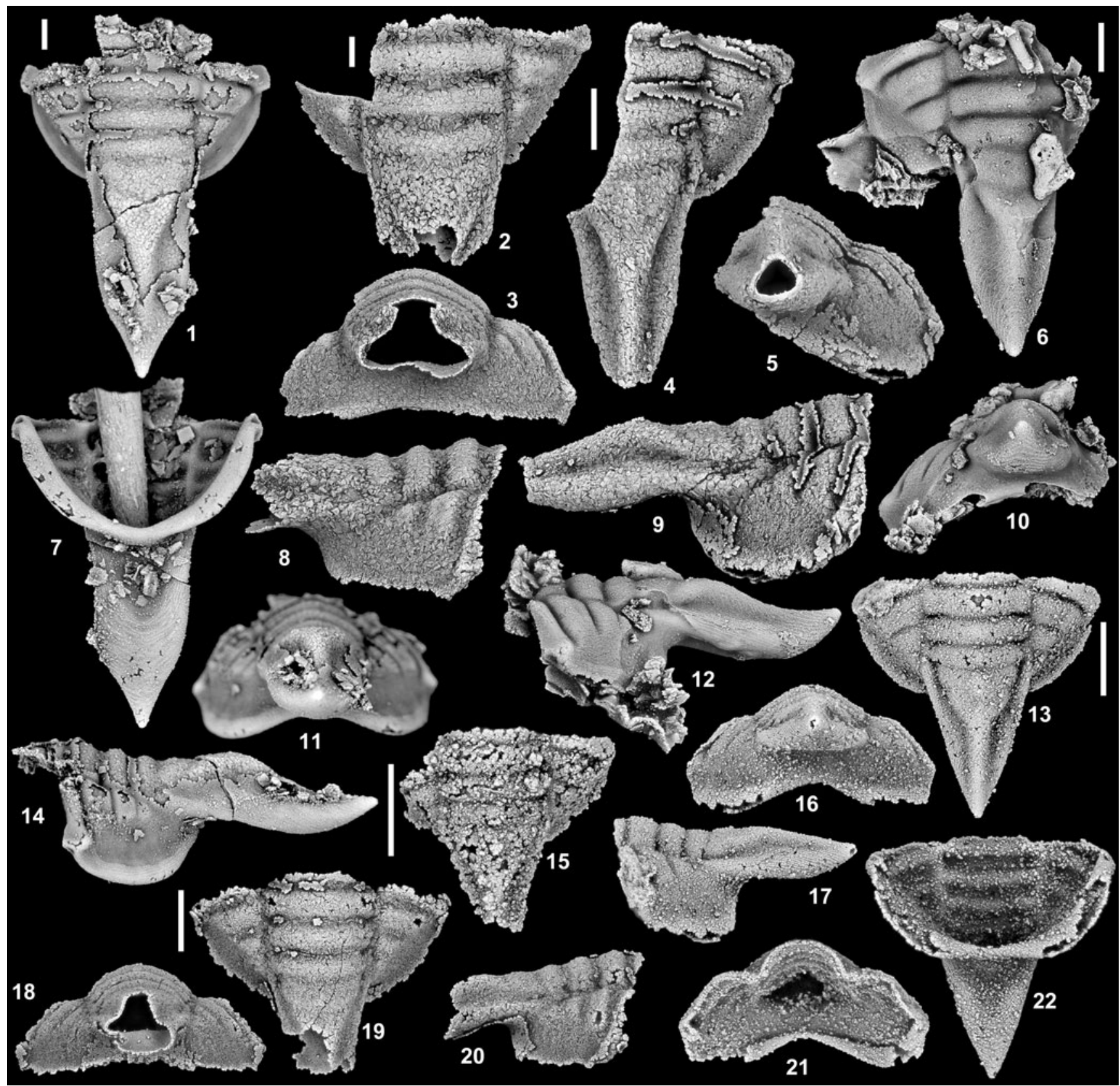

Figure 8. Gonioteloides n. sp. A from Section MME 60.7 m, Fillmore Formation (upper Tremadocian; Stairsian; Unnamed Zone 1), Middle Mountain, Ibex area, Millard County, western Utah, USA. $(\mathbf{1 , 7 , 1 1 , 1 4 )}$ pygidium, SUI 134109, dorsal, ventral (toothpick is holding broken parts of specimen together and could not be masked out), posterior, and left lateral views; $(\mathbf{2}, \mathbf{3 , 8})$ pygidium, SUI 147041, dorsal, posterior, and right lateral views; $(\mathbf{4}, \mathbf{5}, \mathbf{9})$ pygidium, SUI 147042, dorsal, posterior, and right lateral views; $(\mathbf{6}, \mathbf{1 0}, \mathbf{1 2})$ pygidium, SUI 147043, dorsal, posterior, and left lateral views; $(\mathbf{1 3}, \mathbf{1 6}, \mathbf{1 7}, \mathbf{2 1}, \mathbf{2 2})$ pygidium, SUI 147044, dorsal, posterior, left lateral, anterior, and ventral views; (15) pygidium, SUI 147045, dorsal view; (18-20) pygidium, SUI 147046, posterior, dorsal, and right lateral views. Scale bars $=1 \mathrm{~mm}$.

curved forward; posterior border shortest (exsag.) adjacent to LO, with length here $11.2 \%(9.5-13.4 \%)$ that of LO, lengthening abaxially; SO shallow, medial portion slightly deeper on most specimens, confluent with axial furrows; LO large, with length (sag.) $22.1 \%(19.3-24.5 \%)$ that of glabella (sag.), anterior and posterior margins very gently bowed posteriorly, lateral margins angled so that LO has subtrapezoidal outline and distance (tr.) across posterior margin is slightly greater than that across anterior margin; short (sag., exsag.) lenticular shaped doublure present beneath LO, with anterior margin extending only about to midline (tr.) of LO, doublure very gently concave with weak rim developed along posterior margin; very thin strip of doublure present ventrally along posterior margin of posterior projection, strip becomes slightly longer (exsag.) abaxially terminating in a short anteriorly directed subtriangular projection (e.g., Fig. 10.3); dorsal surface of cranidium generally lacking sculpture, except for series of fine raised lines present on anterior border, in anterior view, lines mirror upward bow of border. 


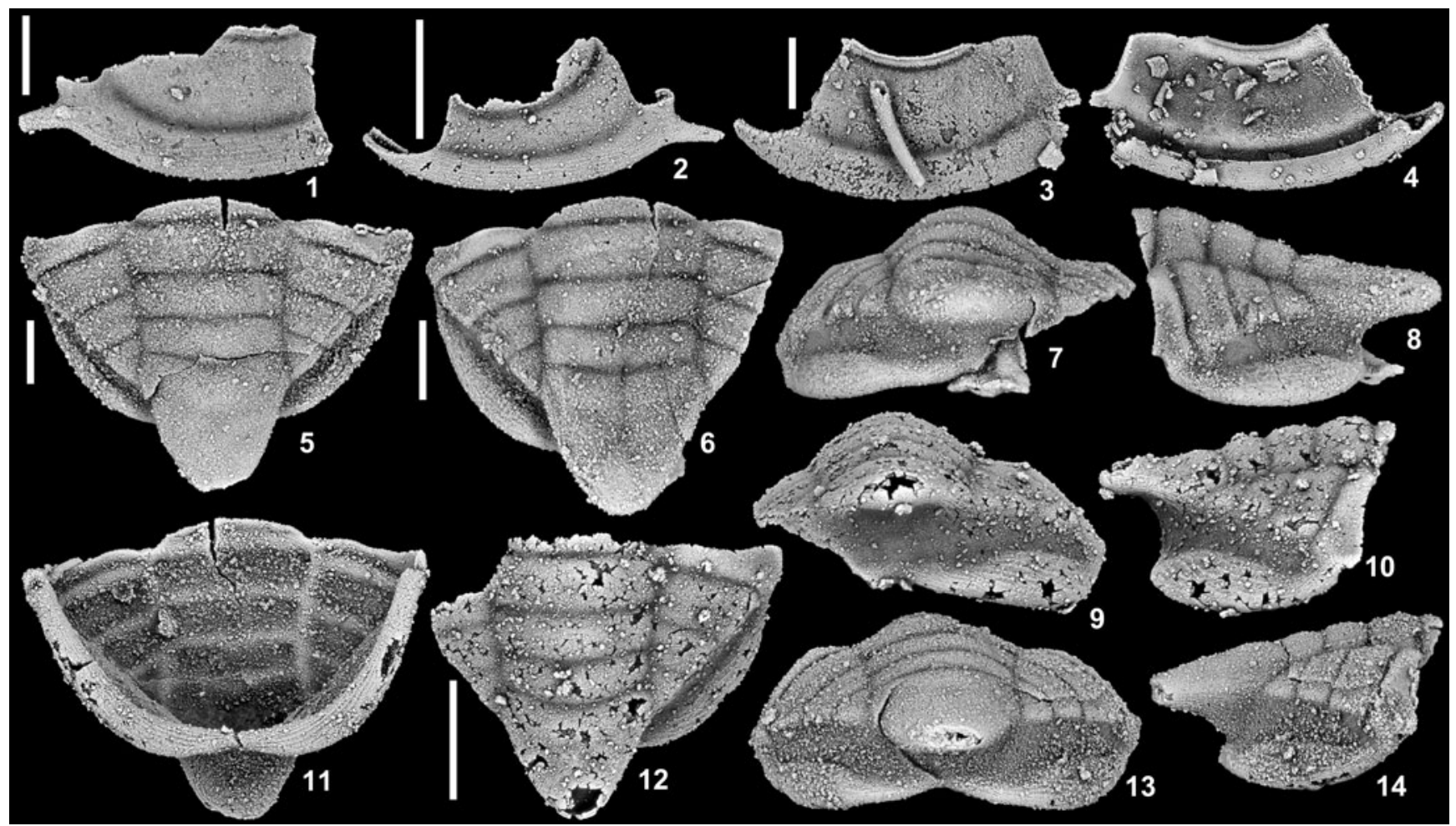

Figure 9. Gonioteloides n. sp. B, from Section AAA 79.5 m, northern House Range, and Section MME 84.0 m, Middle Mountain, both Fillmore Formation (upper Tremadocian; Stairsian; Bearriverops deltaensis Zone), Ibex area, Millard County, western Utah, USA. (1) Right librigena, SUI 147047, external view (AAA 79.5 m); (2) left librigena, SUI 147048, external view (MME 84.0 m); (3, 4) left librigena, SUI 147049, external and internal views (AAA 79.5 m); (5, 11, 13, 14) pygidium, SUI 147050, dorsal, ventral, posterior, and right lateral views (AAA $79.5 \mathrm{~m}$ ); (6-8) pygidium, SUI 147051, dorsal, posterior, and left lateral views (AAA 79.5 $\mathrm{m}) ;(\mathbf{9}, \mathbf{1 0}, \mathbf{1 2})$ pygidium, SUI 134147, posterior, right lateral, and dorsal views (MME $84.0 \mathrm{~m})$. Scale bars $=1 \mathrm{~mm}$.

Librigena overall longer and narrower (compared with $G$. monoceros or G. moffitti n. sp.), relatively flattened with low dorsoventral inflation; lateral margin of librigena (excluding genal spine) describing gentle nearly even curve; eye very long occupying about three-fourths of length of field; visual surface preserved on several specimens, long and broad, crescent shaped in outline with both ends slightly tapered and forming rounded terminations (Fig. 13.13), sitting just above socle; clearly defined, narrow eye socle present beneath visual surface of eye, with very little to almost no inflation; socle separated from eye by very narrow deep furrow, furrow terminated abruptly before reaching anterior facial suture on some specimens (Fig. 13.25); similarly narrow and deep socle furrow present separating socle from genal field; field broad, smooth, slightly broader posteriorly than anteriorly, weak dorsoventral inflation (e.g., Fig. 11.13); anterior facial suture with section adjacent to field straight, strongly bent at border furrow forming an obtuse angle with sector opposite anterior projection, bend forming a tight, but smooth curve, portion of suture along anterior projection concave and longer than that opposite field; posterior facial suture convex opposite field, very short concave section crossing rear border; length of posterior facial suture opposite field longer than that of anterior facial suture across field; anterior projection very long, strongly curved anteromedially, with doublural sector visible in external view; lateral border narrow along entire course, appearing flattened with weak dorsoventral inflation; genal spine present on all specimens as short, slender, thorn-like with base narrow and tapered posteriorly ending in sharp point, directed obliquely; posterior border just barely present, with very small section developed adaxially past genal spine; posterior border furrow not expressed; sculpture of fine raised lines present along anterior projection and majority of lateral border, except for smooth area along inner margin of border toward genal angle, lines continue along lateral margin of lateral border onto lateral face of genal spine, lines closely spaced, subparallel to anastomosing; lines continue ventrally onto outer portion of doublure and along ventral portion of anterior projection, inner margin of doublure beneath lateral border smooth (Fig. 13.27); very faint, fine lines present on lateral face of genal spine (e.g., Fig. 13.17); doublure present beneath lateral border and anterior projection, strongly rolled upward toward ventral surface of border, extending most of way across ventral expression of border, but ending before reaching lateral border furrow; very small section of doublure present beneath posterior border and adjacent to base of genal spine, with prominent notch present along inner margin (Figs. 11.10, 11.12, 13.26, 13.27).

Hypostome and rostral plate not recovered.

Thorax known from a section of several articulated thoracic segments and a few additional segments semi-articulated with a pygidium (see Fig. 14). Thorax generally with very weak dorsoventral inflation (Fig. 14.7, 14.8), axis broad (tr.), wider than pleurae, fulcrum set close to axis, dorsal surface smooth; articulating half ring long (sag.), with length nearly two thirds that of axial ring, anterior margin bowed forward, posterior margin transverse; articulating furrow relatively shallow, but clearly 


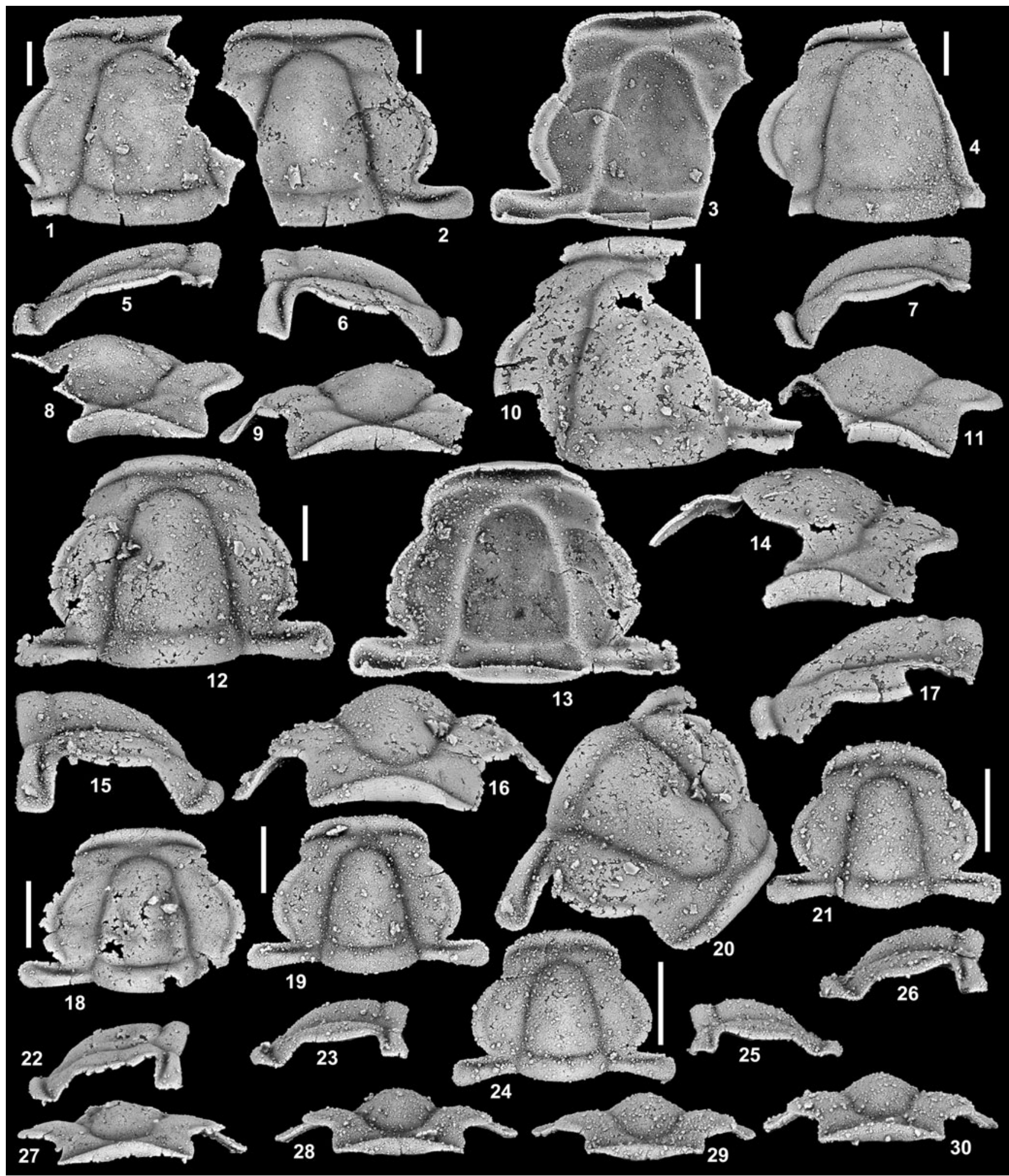

Figure 10. Gonioteloides pankowskii $\mathrm{n}$. sp. from Section MME $75.5 \mathrm{~m}$ (except where indicated) and $76.0 \mathrm{~m}$ (where indicated), Fillmore Formation (upper Tremadocian; Stairsian; Bearriverops loganensis Zone), Middle Mountain, Ibex area, Millard County, western Utah, USA. (1, 5, 8) Cranidium, SUI 147052, dorsal, left lateral, and anterior views; $(\mathbf{2 , 3 , 6 , 9 )}$ cranidium, SUI 147053, dorsal, ventral, right lateral, and anterior views; $(\mathbf{4 , 7}, \mathbf{1 1})$ cranidium, SUI 147054, dorsal, left lateral, and anterior views; $(\mathbf{1 0}, \mathbf{1 4}, \mathbf{1 7})$ cranidium, SUI 147055, dorsal, anterior, and left lateral views; $(\mathbf{1 2}, \mathbf{1 3}, \mathbf{1 5}, \mathbf{1 6}, \mathbf{2 0})$ cranidium, SUI 134114, dorsal, ventral, right lateral, anterior, and oblique views; (18, 22, 27) cranidium, SUI 147056, dorsal, left lateral, and anterior views (MME 76.0T m); (19, 23, 28) cranidium, SUI 147057, dorsal, left lateral, and anterior views; $(\mathbf{2 1}, \mathbf{2 6}, \mathbf{3 0})$ cranidium, SUI 147058, dorsal, left lateral, and anterior views; $(\mathbf{2 4 , 2 5 , 2 9 )}$ cranidium, SUI 147059, dorsal, right lateral, and anterior views. Scale bars $=1 \mathrm{~mm}$. 


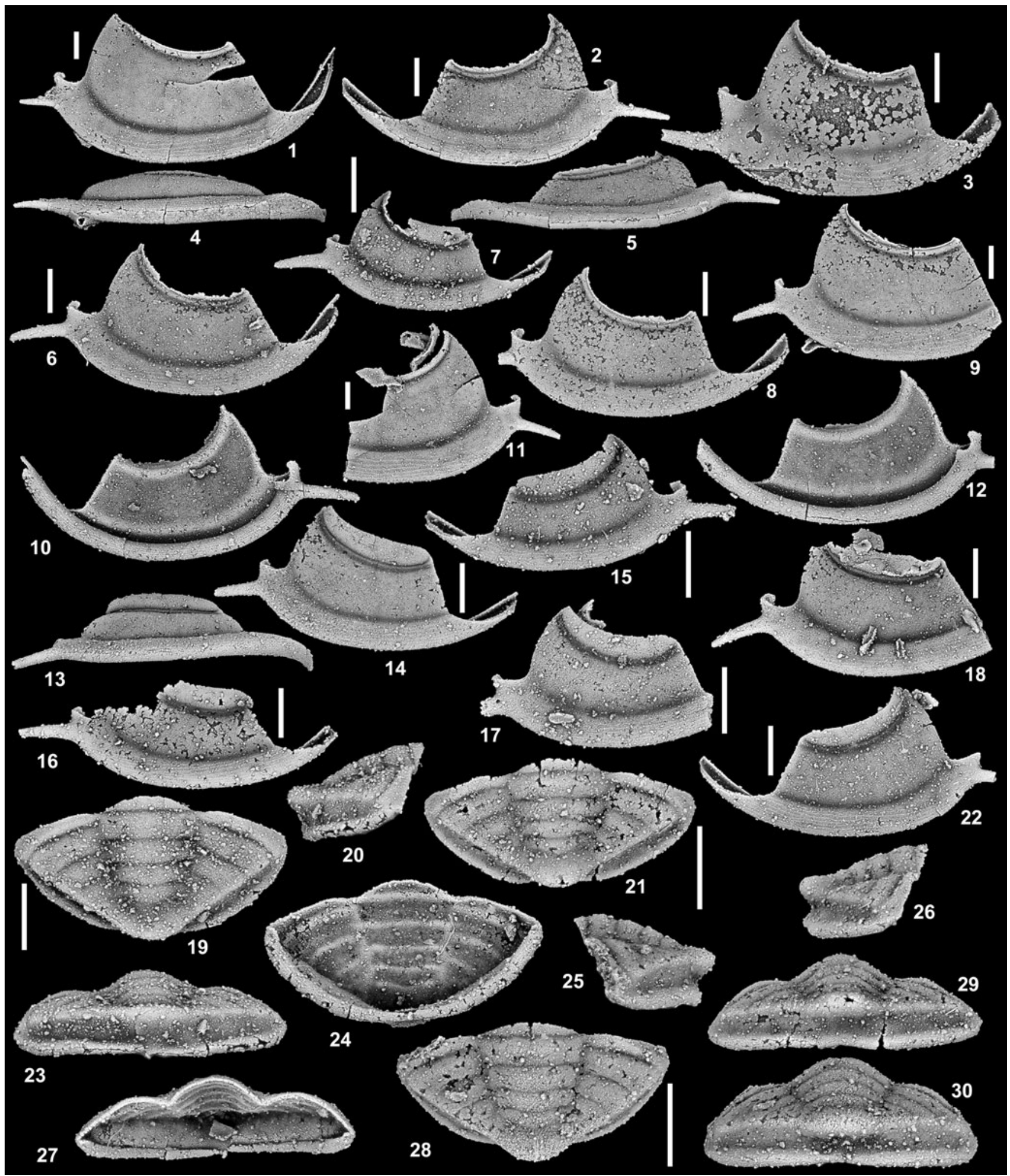

Figure 11. Gonioteloides pankowskii $\mathrm{n}$. sp. from Section MME $75.5 \mathrm{~m}$ (except where indicated) and $76.0 \mathrm{~m}$ (where indicated), Fillmore Formation (upper Tremadocian; Stairsian; Bearriverops loganensis Zone), Middle Mountain, Ibex area, Millard County, western Utah, USA. (1, 4) Right librigena, SUI 147060, external and ventrolateral views; $(\mathbf{2}, \mathbf{5})$ left librigena, SUI 147061, external and ventrolateral views; (3) right librigena, SUI 147062, external view; (6, 10) right librigena, SUI 147063, external and internal view; (7) right librigena, SUI 147064, external view; (8, 12) right librigena, SUI 147065, external and internal views; (9) right librigena, SUI 147066, external view; (11) left librigena, SUI 147067, external view; (13,14) right librigena, SUI 147068, ventrolateral and external views; (15) left librigena, SUI 147069, external view; (16) right librigena, SUI 147070, external view (MME 76.0T m); (17) right librigena, SUI 147071, external view; (18) right librigena, SUI 147072, external view; (19, 20, 23, 24, 27) pygidium, SUI 147073, dorsal, right lateral, posterior, ventral, and anterior views; (21, 26, 29) pygidium, SUI 147074, dorsal, right lateral, and posterior views; (22) left librigena, SUI 147075, external view; (25, 28, 30) pygidium, SUI 134115, left lateral, dorsal, and posterior views. Scale bars $=1 \mathrm{~mm}$ 


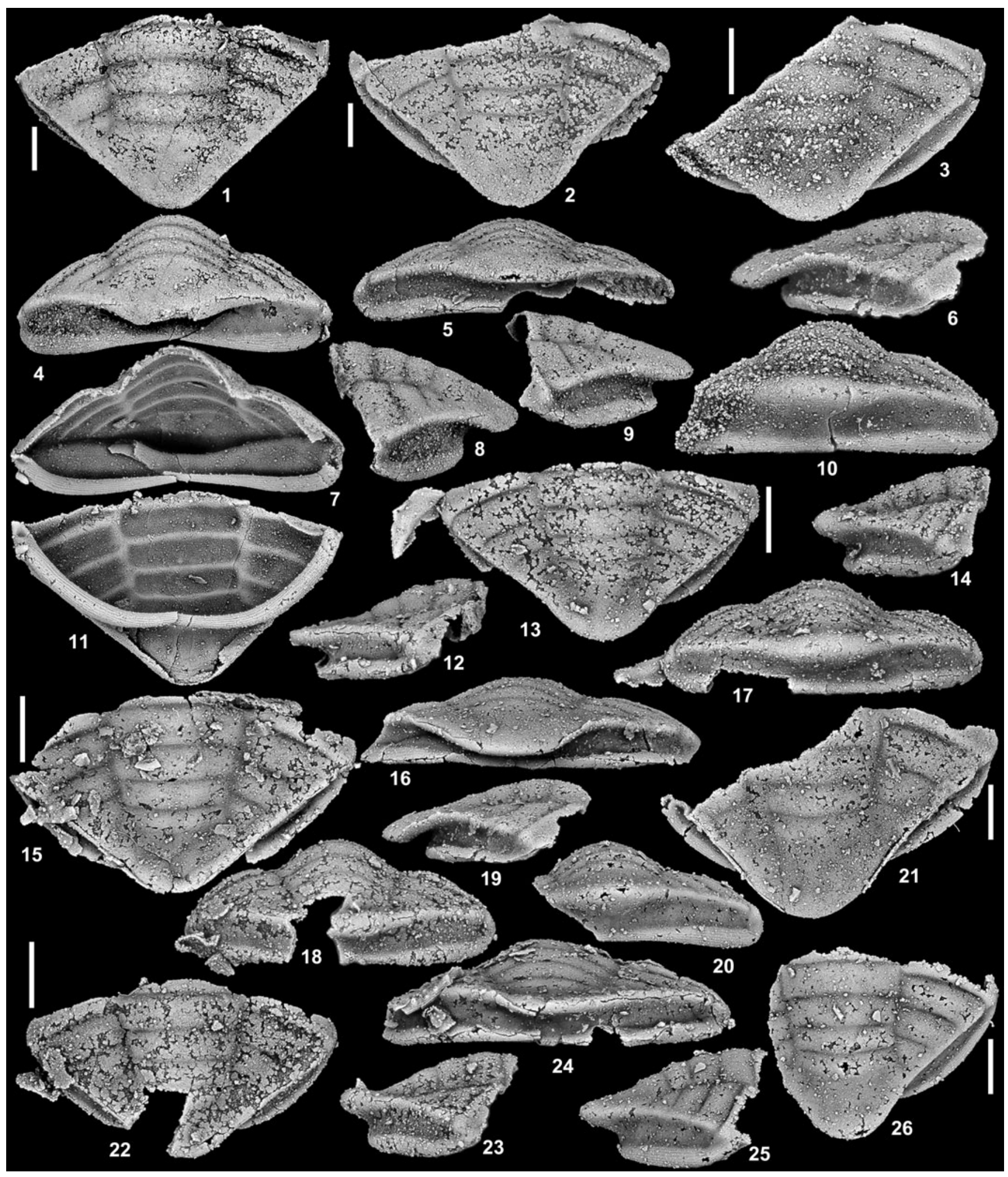

Figure 12. Gonioteloides pankowskii n. sp. from Section MME 75.5 m, Fillmore Formation (upper Tremadocian; Stairsian; Bearriverops loganensis Zone), Middle Mountain, Ibex area, Millard County, western Utah, USA. (1, 4, 7, 8, 11) Pygidium, holotype, SUI 147076, dorsal, posterior, anterior, left lateral, and ventral views $(\mathbf{2 , 5 , 9 )}$ pygidium, SUI 147077, dorsal, posterior, and left lateral views; $(\mathbf{3 , 6}, \mathbf{1 0})$ pygidium, SUI 147078, dorsal, right lateral, and posterior views; $(\mathbf{1 2}, \mathbf{1 5}, \mathbf{2 4})$ pygidium, SUI 147079, right lateral, dorsal, and posterior views; (13, 14, 17) pygidium, SUI 147080, dorsal, right lateral, and posterior views; (16, 19, 21) pygidium, SUI 147081, posterior, right lateral, and dorsal views; (18, 22, 23) pygidium, SUI 147082, posterior, dorsal, and right lateral views; (20, 25, 26) pygidium, SUI 147083, posterior, right lateral, and dorsal views. Scale bars $=1 \mathrm{~mm}$. 


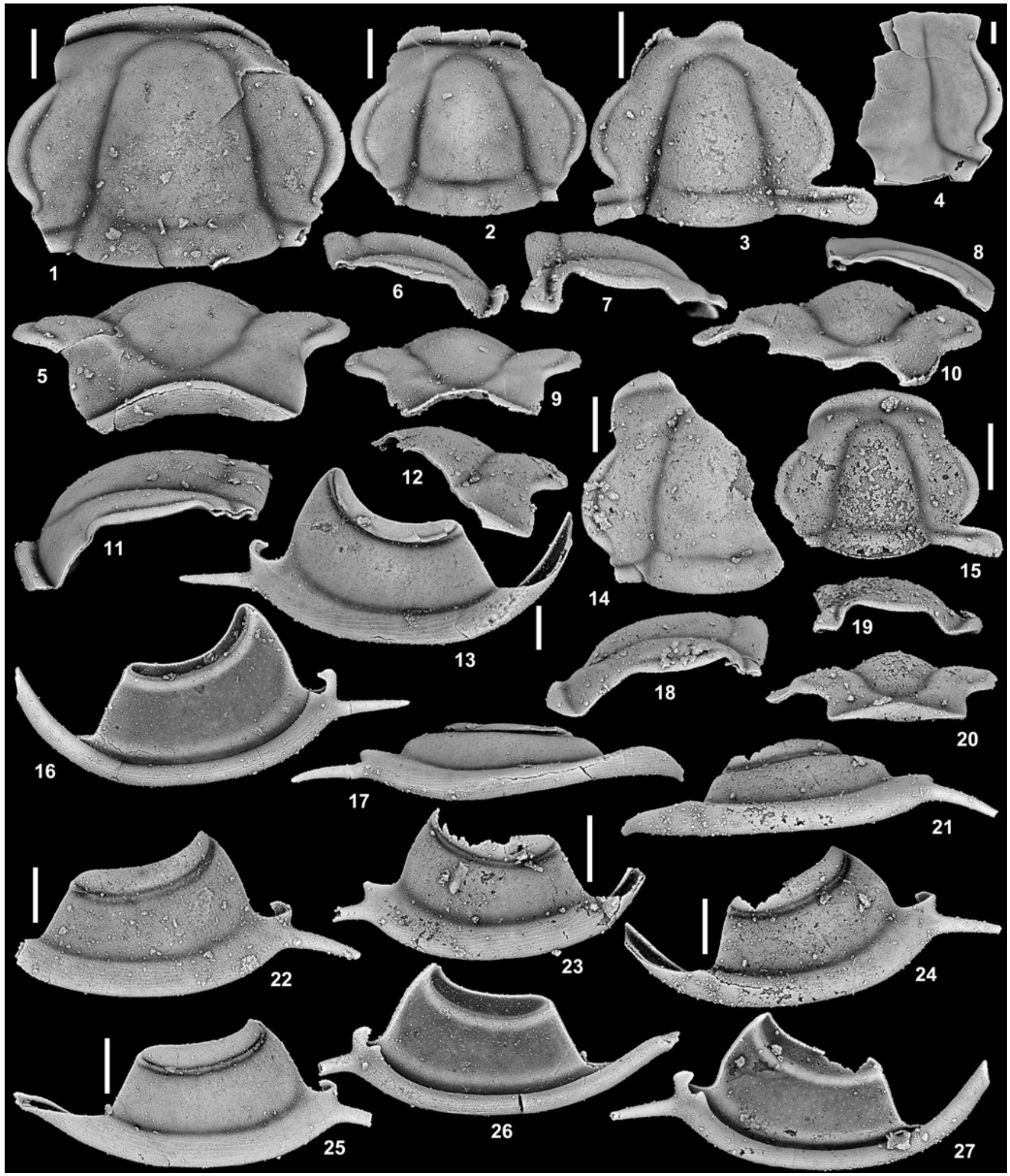

Figure 13. Gonioteloides pankowskii n. sp. from Section HC5 $106.7 \mathrm{~m}$ (east side of Hillyard Canyon), Section HC6 88.3 and $89.5 \mathrm{~m}$ (west side of Hillyard Canyon), and Section FB7 102.1 m (Franklin Basin), all Garden City Formation (upper Tremadocian; Stairsian; Bearriverops loganensis Zone), Bear River Range, Franklin County, southeastern Idaho, USA. (1, 5, 11) Cranidium, SUI 147084, dorsal, anterior, and left lateral views (HC6 88.3 m); (2, 6,9) cranidium, SUI 147085, dorsal, right lateral, and anterior views (HC5 $106.7 \mathrm{~m}) ;(\mathbf{3 , 7 , 1 0})$ cranidium, SUI 147086, dorsal, right lateral, and anterior views $(\mathrm{HC} 5106.7 \mathrm{~m}) ;(\mathbf{4 , 8}) \mathrm{cranidium}$, SUI 147087, dorsal and right lateral views (HC5 106.7 m); (12, 14, 18) cranidium, SUI 147088, anterior, dorsal, and left lateral views (HC5 106.7 m); (13, 16, 17) right librigena, SUI 147089, external, internal, and ventrolateral views (HC5 $106.7 \mathrm{~m}) ;(\mathbf{1 5}, \mathbf{1 9}, \mathbf{2 0})$ cranidium, SUI 147090, dorsal, right lateral, and anterior views (HC 689.5 m); (21, 24, 27) left librigena, SUI 147091, ventrolateral, external, and internal views (FB7 $102.1 \mathrm{~m}$ ); (22) left librigena, SUI 147092, external view (HC5 106.7 m); (23) right librigena, SUI 147093, external view (FB7 $102.1 \mathrm{~m}) ;(\mathbf{2 5}$, 26) left librigena, SUI 147094, external and internal views (HC5 $106.7 \mathrm{~m})$. Scale bars $=1 \mathrm{~mm}$ 


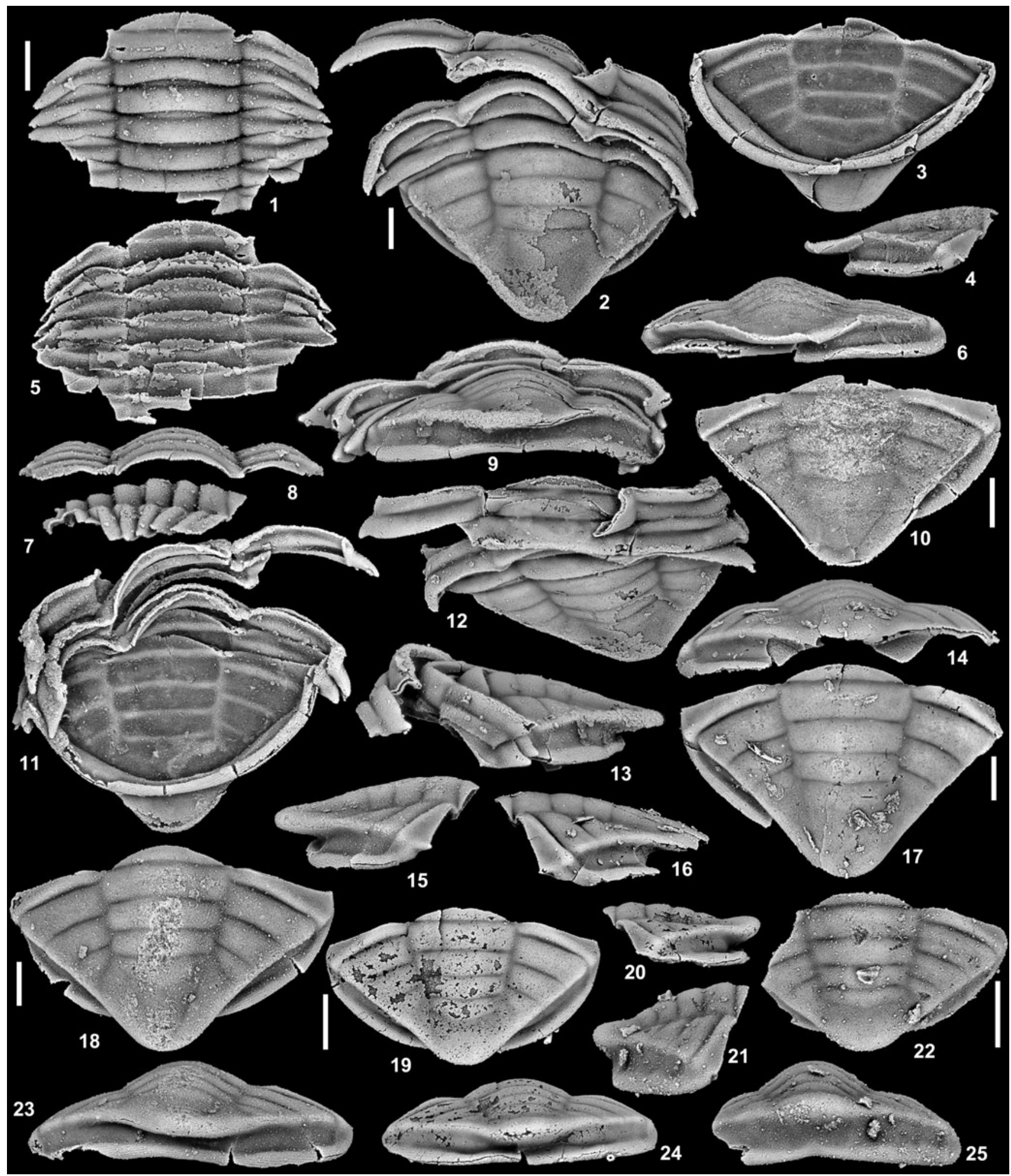

Figure 14. Gonioteloides pankowskii n. sp. from Section HC5 $106.7 \mathrm{~m}$ (except where indicated; east side of Hillyard Canyon), and Section FB7 $102.1 \mathrm{~m}$ (where indicated; Franklin Basin), both Garden City Formation (upper Tremadocian; Stairsian; Bearriverops loganensis Zone), Bear River Range, Franklin County, southeastern Idaho, USA. (1, 5, 7, 8) Thoracic segments, SUI 147095, dorsal, ventral, right lateral, and anterior views; (2, 9, 11-13) pygidium and thoracic segments, SUI 147096, dorsal pygidial, posterior, ventral pygidial, dorsal thoracic, and left lateral views; $(\mathbf{3}, \mathbf{4 , 6}, \mathbf{1 0})$ pygidium, SUI 147097, ventral, right lateral, posterior, and dorsal views; $(\mathbf{1 4 , 1 6 , 1 7 )}$ pygidium, SUI 147098, posterior, left lateral, and dorsal views; $(\mathbf{1 5}, \mathbf{1 8 , 2 3})$ pygidium, SUI 147099 , right lateral, dorsal, and posterior views; $(\mathbf{1 9}, \mathbf{2 0}, \mathbf{2 4})$ pygidium, SUI 147100, dorsal, left lateral, and posterior views; $(\mathbf{2 1 , 2 2 , 2 5})$ pygidium, SUI 147101, right lateral, dorsal, and posterior views $(\mathrm{FB} 7102.1$ $\mathrm{m})$. Scale bars $=1 \mathrm{~mm}$. 


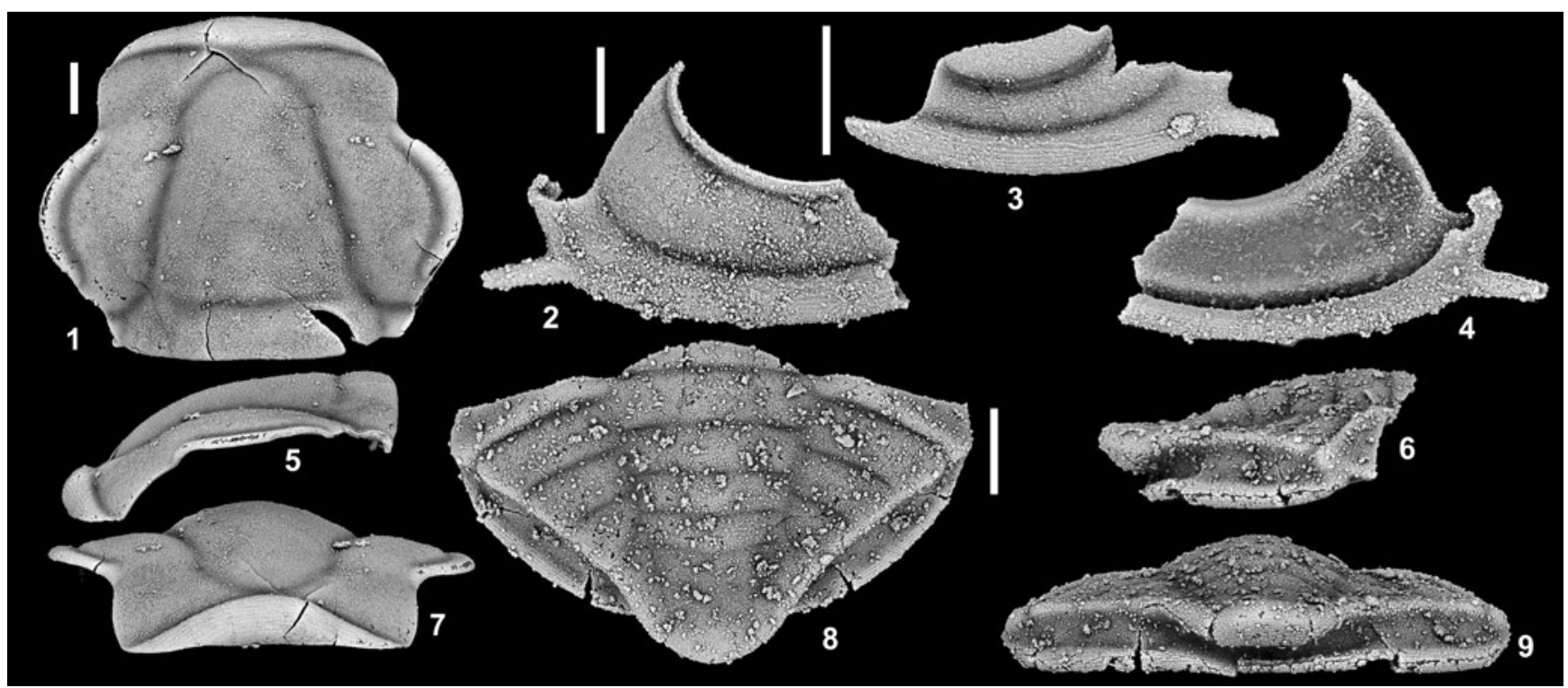

Figure 15. (1-5, 7) Gonioteloides $\mathrm{n}$. sp. C from Section G $26.6 \mathrm{~m}, 27.0 \mathrm{~m}$, and 27.5T m, Fillmore Formation (upper Tremadocian; Stairsian; Bearriverops alsacharovi Zone), southern Confusion Range, Ibex area, Millard County, western Utah, USA. (1, 5, 7) Cranidium, SUI 147102, dorsal, left lateral, and anterior views (G $27.5 \mathrm{~T} \mathrm{~m}) ;(\mathbf{2 , 4})$ right librigena, SUI 147103, external and internal views (G $27.0 \mathrm{~m}) ;(\mathbf{3})$ left librigena, SUI 147104, external view (G 26.6 m). (6, 8,9) Gonioteloides pankowskii n. sp. from Section MME 84.0 m, Middle Mountain, Fillmore Formation (upper Tremadocian; Stairsian; Bearriverops deltaensis Zone), Ibex area, Millard County, western Utah, USA; pygidium, SUI 148369, right lateral, dorsal, and posterior views. Scale bars $=1 \mathrm{~mm}$.

incised along entire course, transverse; axial segment broad (tr.), generally subrectangular in outline, with the posterior margin of some segments slightly bowed forward medially so that articulating half ring of subsequent segment is exposed; axial furrow relatively shallow, but clearly expressed; pleurae with anterior and posterior bands expressed, adjacent to axial furrow anterior band is shorter (exsag.) and nearly pinched out compared to posterior band, anterior band quickly lengthened to achieve more typical length (exsag.) for remainder of lateral extent; portion of pleurae between axis and fulcrum held subparallel to transverse axis, portion distal to fulcrum directed posterolaterally (degree appears to depend on position in thorax); pleural furrows clearly developed, confluent with axial furrow, medial section slightly longer (exsag.) (see Fig. 14.12), furrow much shallower distally; micro-articulating spike present on anterolateral corner of anterior pleural band (Fig. 14.13); distal termination of posterior pleural band developed into short spine-like projection (Fig. 14.12), directed posteriorly and flexed downward from horizontal plane; doublure present beneath distal tip of pleura and spine with sculpture of very faint, fine raised lines present; small articulating socket appears present along anterior face of doublure at termination of anterior pleural band (see tip of partially disassociated segment on Fig. 14.11).

Pygidium with main pleural region and axis forming subtriangular upper sector of pygidium situated upon very short dorsoventrally oriented "wall," with pygidial border describing semi-elliptical outline below (see ventral views); upper subtriangular sector with length (excluding articulating half ring) 55.6\% (51.1-60.2\%) width (tr.); pygidium with low dorsoventral inflation, height primarily due to short "wall" developed between pygidial border and upper rim formed by pleural tips and posterior projection; portion of lower pygidial border opposite pleurae extended a short distance laterally past upper rim so that a small sliver is visible in dorsal view, rear portion of border obscured by posterior projection in dorsal view; articulating half-ring short, with length (sag.) 46.7\% (42.0-51.0\%) length of first axial ring (sag.), anterior margin gently arched, posterior margin nearly transverse; axis composed of four segments, widest (tr.) across first segment, gently tapered posteriorly and slightly pinched (tr.) at third ring furrow (more obvious on some specimens than others), width across first axial segment $129.8 \%$ (120.6-138.2\%) width across third ring furrow; axis with low independent dorsal inflation; first axial segment longest of the four, with length (sag., exsag.) similar across segment; second and third axial segments progressively shorter and with sagittal length slightly longer than exsagittal length; fourth segment expressed, even on larger specimens, but with posterior margin not always clearly defined; posterior projection extends short distance beyond posterior pygidial border, small and broad, bluntly rounded, in lateral profile projection apparently held subparallel to horizontal plane or slightly flexed downward from horizontal plane (difficult to ascertain on many specimens due to slight deformation); ring furrows 1-3 clearly incised, slightly deeper abaxially just before reaching axial furrow (more pronounced on smaller specimens; e.g., Fig. 14.22); axial furrow slightly bowed outward around lateral margins of first three rings, significantly shallower to nearly effaced opposite fourth ring; anterior margin of pleural region sloped gently posterolaterally, with fulcrum set close to axis; distinct, short, thorn-like spike developed at anterolateral corner of pygidium (e.g., Fig. 14.15); pleural region composed of four segments, with first segment widest (tr.), subsequent segments progressively narrower; pleural tips and posterior projection forming distinctive linear rim around upper margin of pygidium, course of rim with slight inflection at intersection of pleurae and posterior projection, with distal tip of anterior band of first segment extended farther laterally, set off from main portion of this rim and forming a distinct knob (see lateral profile, e.g., Fig. 14.16); distal tip 
of anterior band of first segment also confluent with lower border of pygidium, outlining the anterior margin of the short vertical wall between the upper linear rim and the lower pygidial border; first pleural furrow deepest and longest (exsag.), with subsequent furrows progressively shallower and fourth furrow nearly effaced on some specimens; interpleural furrows effaced; very short "wall" developed between upper portion of pygidium and lower pygidial border, there appears to be a short (dorsoventral) indentation between the base of the posterior projection and the posterior border (e.g., Fig. 12.8, 12.9, 12.20); lateral and posterior borders forming an inflated rolled rim around margin, border narrower posteriorly beneath posterior projection, in posterior view border gently flexed upward along sagittal axis forming a small peak medially (Fig. 14.25); doublure beneath whole of border, folded upward toward ventral surface (e.g., Fig. 12.7); small pit present at anterolateral corner of doublure (Fig. 12.11); lateral and posterior borders with fine raised lines running roughly parallel to pygidial margin, sculpture continues ventrally onto surface of doublure (Fig. 12.7, 12.11); sculpture of raised lines also present on ventral surface of posterior projection along outer surface, with medial portion of ventral surface smooth (Fig. 14.3), lines are more closely spaced along outer margin of projections with spacing between lines increasing moving away from margin toward middle of projection.

\section{Etymology.-After Mark Pankowski.}

Materials.-In addition to the holotype, SUI 134114, 134115, 147052-147075, 147077-147101, 148369.

Ontogeny.-Dorso-ventral inflation of the cranidium increases somewhat throughout ontogeny, with the anterior fixigena becoming more strongly downturned from horizontal plane. The glabella is proportionally longer (sag.) and narrower (tr.) on smaller specimens, with larger specimens possessing a glabella that is broader (tr.) relative to length (sag.). A thin strip of preglabellar field is present on smaller specimens. It is reduced throughout ontogeny so that on most larger specimens the preglabellar field is pinched out medially and the anterior border and preglabellar furrows are in contact for a wider (tr.) stretch. The posterior margin of the anterior border is more uniformly anteriorly bowed on smaller specimens, with the slight posterior bow of the median sector developing later and present on larger specimens. The ventral margin of the anterior border in anterior view is transverse to outwardly convex, giving the anterior border a lenticular shape in some specimens (e.g., Fig. 10.28, 10.29). It becomes more strongly upwardly arched throughout ontogeny. The furrow separating preocular and interocular fixigena is absent on smaller specimens, but becomes more pronounced on larger specimens. The smallest pygidia recovered show the axis lengthening throughout ontogeny, with the posterior projection also becoming longer and extending farther beyond the pygidial border. On the smallest specimens, the posterior projection forms a small nubbin in lateral profile extending just beyond the pygidial border. The first three axial ring furrows on smaller pygidia display clearly deeper abaxial sections adjacent to the axial furrow on smaller specimens (e.g., Fig. 14.22). This difference in depth of the furrow becomes less prominent on larger specimens so that it is not dramatically deeper than rest of ring furrow. The posterior margin of the fourth axial ring is clearly defined on the smallest specimens, but becomes progressively effaced throughout ontogeny so that it can be discerned on larger specimens more by a difference in inflation.

Remarks.-Differences between the non-vaulted species group comprising G. pankowskii n. sp. and Gonioteloides n. sp. C were discussed under remarks on the genus. Gonioteloides n. sp. C is known only from a single pygidium and two librigenae. The cranidium of G. pankowskii n. sp. is almost indistinguishable from that of Gonioteloides n. sp. C. The palpebral lobes of G. pankowskii n. sp. are slightly longer, and the axial furrows are deeper and cut across the posterior border with only slight deflection, whereas in the single specimen of Gonioteloides n. sp. C, the furrow is deflected laterally in front of the border, then turned posteriorly as a shallow furrow across the border. How meaningful these differences are can only be assessed with a larger sample size of Gonioteloides n. sp. C. Librigenae, on the other hand, are obviously distinct, as seen in similarly sized specimens of Gonioteloides pankowskii n. sp., which have much broader fields than those of Gonioteloides n. sp. C, particularly anteriorly.

It is relatively rare for species to be shared between the Stairsian trilobite zones established by Adrain et al. (2014a). Almost all material of G. pankowskii n. sp. is from the Bearriverops loganensis Zone. A single pygidium from the overlying B. deltaensis Zone (Fig. 15.6, 15.8, 15.9) seems indistinguishable from those sampled from the $B$. loganensis Zone, and the species appears to have ranged up. There is precedent for this-Adrain and Karim (2019) found that the cheirurid species Tesselacauda depressa Ross, 1951, also ranged between the zones.

\section{Gonioteloides new species C Figure 15.1-15.5, 15.7}

Occurrence.-Section G $26.6 \mathrm{~m}$ and G 27.5T m, Fillmore Formation (upper Tremadocian; Stairsian; Bearriverops alsacharovi Zone), southern Confusion Range, Ibex area, Millard County, western Utah.

\section{Materials.—Assigned specimens SUI 147102-147104.}

Remarks.—Gonioteloides n. sp. C is compared with G. pankowskii n. sp. above. The species occurs together with $G$. monoceros, but its rare sclerites are impossible to confuse with those of that much more vaulted species. Similarly sized librigenae of Gonioteloides n. sp. C have narrower lateral borders, with only very fine, versus prominent raised line, sculpture, much narrower fields, and retain a thorn-like spine versus losing it in larger specimens (compare the similarly sized species of Fig. 2.12 and Fig. 15.2).

\section{Acknowledgments}

S. Westrop, B. Beck, N. McAdams, S. Losso, and R. Ng collaborated or assisted with various aspects of field work. A. Bradley 
assisted with field work and read the manuscript. T. Adrain assisted with curation and SUI specimen numbers. We are grateful for reviews by L. Amati and T.-Y. Park that improved the paper.

\section{References}

Adrain, J.M., 2011, Class Trilobita Walch, 1771, in Zhang, Z.-Q., ed., Animal Biodiversity: An Outline of Higher-level Classification and Survey of Taxonomic Richness: Zootaxa, v. 3148, p. 104-109.

Adrain, J.M., 2013, A synopsis of Ordovician trilobite distribution and diversity, in Harper, D.A.T., and Servais, T., eds., Early Palaeozoic Biogeography and Palaeogeography: Geological Society, London, Memoirs, v. 38, p. 297-336.

Adrain, J.M., and Karim, T.S., 2019, Revision of the Early Ordovician (late Tremadocian; Stairsian) cheirurid trilobite Tesselacauda Ross, with species from the Great Basin, western USA: Zootaxa, v. 4661, p. 201-255.

Adrain, J.M., and Westrop, S.R., 2007, Bearriverops, a new Lower Ordovician trilobite genus from the Great Basin, western USA, and classification of the family Dimeropygidae: Canadian Journal of Earth Sciences, v. 44, p. 337 366.

Adrain, J.M., Lee, D.-C., Westrop, S.R., Chatterton, B.D.E., and Landing, E., 2003. Classification of the trilobite subfamilies Hystricurinae and Hintzecurinae subfam. nov., with new genera from the Lower Ordovician (Ibexian) of Idaho and Utah: Memoirs of the Queensland Museum, v. 48, p. 553-586.

Adrain, J.M., McAdams, N.E.B., and Westrop, S.R., 2009, Trilobite biostratigraphy and revised bases of the Tulean and Blackhillsian Stages of the Ibexian Series, Lower Ordovician, western United States: Memoirs of the Association of Australasian Palaeontologists, v. 37, p. 541-610.

Adrain, J.M., McAdams, N.E.B., Westrop, S.R., and Karim, T.S., 2011, Systematics and affinity of the Lower Ordovician (Tulean; lower Floian) trilobite Psalikilopsis: Memoirs of the Association of Australasian Palaeontologists, v. 42, p. 369-416.

Adrain, J.M., Karim, T.S., Westrop, S.R., and Landing, E., 2014a, Trilobite biostratigraphy of the Stairsian Stage (upper Tremadocian) of the Ibexian Series, Lower Ordovician, western United States: Memoirs of the Association of Australasian Palaeontologists, v. 45, p. 167-214.

Adrain, J.M., Karim, T.S., and Westrop, S.R., 2014b, The Early Ordovician (late Tremadocian; Stairsian) dimeropygid trilobite Pseudohystricurus Ross: Memoirs of the Association of Australasian Palaeontologists, v. 45, p. 215-232.

Aitken, J.D., and Norford, B.S., 1967, Lower Ordovician Survey Peak and Outram formations, southern Rocky Mountains of Alberta: Bulletin of Canadian Petroleum Geology, v. 15, p. 150-207.

Berg, R.R., and Ross, R.J., Jr, 1959, Trilobites from the Peerless and Manitou formations, Colorado: Journal of Paleontology, v. 33, p. 106-119.

Boyce, W.D., 1989, Early Ordovician trilobite faunas of the Boat Harbour and Catoche formations (St. George Group) in the Boat Harbour-Cape Norman area, Great Northern Peninsula, western Newfoundland: Newfoundland Department of Mines and Energy, Geological Survey Branch, Report, v. 89-2, 169 p.

Brett, K.D., and Westrop, S.R., 1996, Trilobites of the Lower Ordovician (Ibexian) Fort Cassin Formation, Champlain Valley regions, New York State and Vermont: Journal of Paleontology, v. 70, p. 408-427.

Chatterton, B.D.E., 1994, Ordovician proetide trilobite Dimeropyge, with a new species from northwestern Canada: Journal of Paleontology, v. 68, p. 541556.

Dean, W.T., 1978, Preliminary account of the trilobite biostratigraphy of the Survey Peak and Outram formations (late Cambrian, Early Ordovician) at Wilcox Pass, southern Canadian Rocky Mountains, Alberta: Geological Survey of Canada Paper, v. 76-34, p. 1-10.

Dean, W.T., 1989, Trilobites from the Survey Peak, Outram and Skoki formations (upper Cambrian-Lower Ordovician) at Wilcox Pass, Jasper National Park, Alberta: Geological Survey of Canada Bulletin, v. 389, p. 1-141.

Dean, W.T., and Martin, F., 1982, The sequence of trilobite faunas and acritarch microfloras at the Cambrian-Ordovician boundary, Wilcox Pass, Alberta, Canada: National Museum of Wales, Geological Series, p. 131-140.
Fortey, R.A., 1979, Early Ordovician trilobites from the Catoche Formation (St. George Group), western Newfoundland: Geological Survey of Canada Bulletin, v. 321, p. 61-114.

Fortey, R.A., and Bruton, D.L., 2013, Lower Ordovician trilobites of the Kirtonryggen Formation, Spitsbergen: Fossils and Strata, v. 59, 116 p.

Hintze, L.F., 1953, Lower Ordovician trilobites from western Utah and eastern Nevada: Utah Geological and Mineralogical Survey Bulletin, v. 48, 249 p. (for 1952)

Hupé, P., 1953, Classe des Trilobites, in Piveteau, J., ed., Traité de Paléontologie. Tome 3. Les Formes Ultimes d'Invertébrés. Morphologie et Évolution. Onycophores. Arthropodes. Échinoderms. Stomocordés.: Paris, Masson et Cie, p. 44-246.

Jell, P.A., and Adrain, J.M., 2003, Available generic names for trilobites: Memoirs of the Queensland Museum, v. 48, p. 331-553.

Kobayashi, T., 1955, The Ordovician fossils of the McKay Group in British Columbia western Canada, with a note on the early Ordovician palaeogeography: Journal of the Faculty of Science, Tokyo University, Section 2, v. 9, p. 355-493.

Landing, E., Adrain, J.M., Westrop, S.R., and Kröger, B., 2012, Tribes Hill-Rochdale formations in east Laurentia: proxies for Early Ordovician (Tremadocian) eustasy on a tropical passive margin (New York and west Vermont): Geological Magazine, v. 149, p. 93-123.

Lee, D.-C., and Chatterton, B.D.E., 1997, Three new proetide trilobite larvae from the Lower Ordovician Garden City Formation in southern Idaho: Journal of Paleontology, v. 71, p. 434-441.

Loch, J.D., 2007, Trilobite biostratigraphy and correlation of the Kindblade Formation (Lower Ordovician) of Carter and Kiowa counties, Oklahoma: Oklahoma Geological Survey Bulletin, v. 149, 157 p.

McAdams, N.E.B., and Adrain, J.M., 2009, Heckethornia, a new genus of dimeropygid trilobites from the Lower Ordovician (Ibexian; Tulean and Blackhillsian) of the Great Basin, western USA: Canadian Journal of Earth Sciences, v. 46, p. 875-914.

Moore, R.C., 1959, Treatise on Invertebrate Paleontology. Part O. Arthropoda 1: Boulder, CO and Lawrence, KS, Geological Society of America and University of Kansas Press, $560 \mathrm{p}$

Norford, B.S., 1969, The Early Canadian (Tremadocian) trilobites Clelandia and Jujuyaspis from the southern Rocky Mountains of Canada: Geological Survey of Canada Bulletin, v. 182, p. 1-15.

Öpik, A.A., 1937, Trilobiten aus Estland: Tartu Ülikooli Geoloogia-Intituudi Toimetused, v. 52, p. 1-163.

Raymond, P.E., 1925, Some trilobites of the lower Middle Ordovician of eastern North America: Bulletin of the Museum of Comparative Zoology, Harvard University, v. 67 , p. $1-180$

Ross, R.J., Jr., 1949, Stratigraphy and trilobite faunal zones of the Garden City Formation, northeastern Utah: American Journal of Science, v. 247, p. 472-491

Ross, R.J., Jr., 1951, Stratigraphy of the Garden City Formation in northeastern Utah, and its trilobite faunas: Peabody Museum of Natural History, Yale University, Bulletin, v. 6, 161 p.

Ross, R.J., Jr., 1953, Additional Garden City (Early Ordovician) trilobites: Journal of Paleontology, v. 27, p. 633-646.

Ross, R.J., Jr, 1975, Early Paleozoic trilobites, sedimentary facies, lithospheric plates, and ocean currents: Fossils and Strata, v. 4, p. 307-329.

Terrell, F.M., 1973, Silicified trilobite zonation in the Lower Fillmore Formation in western Utah: Brigham Young University Geology Studies, v. 20, p. 67-90.

Walcott, C.D., 1886, Second contribution to the studies on the Cambrian faunas of North America: United States Geological Survey Bulletin, v. 30, 369 p.

Walcott, C.D., 1924, Cambrian geology and palaeontology, V. No. 2-Cambrian and lower Ozarkian trilobites: Smithsonian Miscellaneous Collections, v. 75 , p. 53-60.

Westrop, S.R., Knox, L.A., and Landing, E., 1993, Lower Ordovician (Ibexian) trilobites from the Tribes Hill Formation, central Mohawk Valley, New York State: Canadian Journal of Earth Sciences, v. 30, p. 1618-1633.

Whittington, H.B., 1953, North American Bathyuridae and Leiostegiidae (Trilobita): Journal of Paleontology, v. 27, p. 647-678.

Accepted: 8 April 2021 